\title{
Tropical forage technologies can deliver multiple benefits in Sub-Saharan Africa. A meta-analysis
}

\author{
Birthe K. Paul ${ }^{1,2}$ (1) Jessica Koge ${ }^{1} \cdot$ Brigitte L. Maass $^{3} \cdot$ An Notenbaert $^{1} \cdot$ Michael Peters $^{1} \cdot$ Jeroen C.J. Groot ${ }^{2,4,6}$. \\ Pablo Tittonell ${ }^{4,5,7,8}$
}

Accepted: 28 May 2020 / Published online: 29 June 2020

(C) The Author(s) 2020

\begin{abstract}
Scarcity of quantity and quality feed has been a key constraint to productivity of smallholder crop-livestock systems. Tropical forages include a variety of annual and perennial grasses, herbaceous and dual-purpose legumes, and multipurpose trees and shrubs. They have been promoted in Sub-Saharan Africa (SSA) for increasing livestock productivity and household income through higher quantity and quality of herbage, while contributing to soil improvement and higher food crop yields. For the first time, we quantitatively reviewed 72 experimental studies from across SSA to take stock of geographical distribution and forage technology focus of past research; quantify magnitudes of multidimensional impacts of forage technologies; and present variability in forage agronomy data. Improved forage technologies were classified into four groups: (i) germplasm, (ii) management, (iii) cropping system integration, and (iv) feeding regime. Mean weighted response ratios were calculated from 780 pairs of observations for 13 indicators across the five impact dimensions. Improved forage germplasm had on average 2.6 times higher herbage productivity than local controls, with strongest effect in grasses. Feeding regimes with improved leguminous forages increased milk yield by on average $39 \%$, dry matter intake by $25 \%$, and manure production by $24 \%$. When forage technologies were integrated with food crops, soil loss was almost halved, soil organic carbon increased on average by $10 \%$, and grain and stover yields by $60 \%$ and $33 \%$, respectively. This study demonstrates the central role improved forages could play in sustainable intensification of crop-livestock systems in SSA. It highlights the need for multidisciplinary and systems-level approaches and studies to quantify synergies and tradeoffs between impact dimensions. Further research is needed to explain forage agronomic yield variability, unraveling interactions between genotype, on-farm environmental conditions, and management factors. Results from this review can inform development programs, prioritizing technologies proven successful for dissemination and indicating magnitudes of expected impacts.
\end{abstract}

Keywords Crop-livestock systems $\cdot$ Herbaceous legume $\cdot$ Forage grass $\cdot$ Soil organic carbon $\cdot$ Livestock productivity $\cdot$ Forage agronomy $\cdot$ Cropping system $\cdot$ Multi-dimensional impacts $\cdot$ Sustainable intensification

Birthe K. Paul

b.paul@cgiar.org

1 Tropical Forages Program, International Center for Tropical Agriculture (CIAT) Regional Office for Africa, PO Box 823-00621, c/o ICIPE Duduville Complex, off Kasarani Road, Nairobi, Kenya

2 Farming Systems Ecology, Wageningen University and Research (WUR), Wageningen, The Netherlands

3 Department of Crop Sciences, Faculty of Agricultural Sciences, Georg-August-University of Göttingen, Grisebachstr. 6, 37077 Göttingen, Germany

4 Bioversity International, Development Impact Unit, Viale dei Tre Denari, 472/a, 00054 Maccarese (Fiumicino), Italy
5 Agroecology, Environment and Systems Group, Instituto de Investigaciones Forestales y Agropecuarias de Bariloche (IFAB), INTA-CONICET, Modesta Victoria 4450 - CC 277, 8400 San Carlos de Bariloche, Río Negro, Argentina

6 International Maize and Wheat Improvement Center (CIMMYT), Sustainable Intensification Program, Carretera México-Veracruz, km. 45, El Batán, 56237 Texcoco, México

7 Agroécologie et Intensification Durable (AïDA), Centre de coopération Internationale en Recherche Agronomique pour le Développement (CIRAD), Université de Montpellier, 34000 Montpellier, France

8 Groningen Institute of Evolutionary Life Sciences, Groningen University, PO Box 11103, 9700, CC Groningen, The Netherlands 


\section{Introduction}

Two-thirds of the global rural population are engaged in mixed crop-livestock systems, and these farmers produce around $50 \%$ of the world's cereals, $60 \%$ of meat, and $75 \%$ of milk. Mixed systems enable farmers to synergize between cropping activities and livestock husbandry through draft power for land cultivation, manure application for crop fertilization, and feeding of crop residues and planted forages (Herrero et al. 2010). Scarcity of quantity and quality livestock feed on a consistent basis is often cited as a major constraint faced by mixed crop-livestock farmers in Sub-Saharan Africa (SSA), especially during the dry season. Feed is also a major production cost in dairy production (Bebe et al. 2008; Hall et al. 2007). SSA has one of the lowest feed conversions for milk and meat globally, thus, the highest amounts of feed needed to produce a unit livestock product. This is mainly due to low animal productivity and poor livestock diets in smallholder mixed systems, as they rely on crop residues, grazing, collected vegetation, and other opportunistic feed (Herrero et al. 2013). Crop residues are often of low feed quality, and scarce resources on smallholder farms due to their competing uses as soil amendment (Homann Kee-Tui et al. 2014; Tittonell et al. 2015; Valbuena et al. 2012; Tittonell et al. 2015).

One of the main approaches for addressing the feed scarcity has been to develop improved feed and forage options, and evaluate them for their yield and quality, and impact on livestock productivity parameters (Ayele et al. 2012; Hall et al. 2007). Improved tropical forages include a wide variety of sown or planted grasses, herbaceous or dual-purpose legumes, and multipurpose trees and shrubs (also mostly legumes) that are integrated in agropastoral, silvopastoral, and intensive or extensive mixed agricultural systems for grazing or cut-andcarry (Rao et al. 2015). Intensification with improved forage technologies can take two forms: simple improvements such as the introduction of new forage varieties on-farm and in the existing feeding regime, or more complex sets of new practices that integrate forages in production systems. Forages need to be integrated into cropping systems, especially with food crops, to not compromise smallholders' food security (Ates et al. 2018; Maass et al. 2015; Rudel et al. 2015). Tropical forages can fulfill various objectives and roles in farming systems, and they can occupy different spatial and temporal niches. In a crop role, herbaceous and dual-purpose legumes can be sown on arable land to meet short-term or seasonal fodder needs; in a niche role, herbaceous and dual-purpose legumes and trees/shrubs can be grown on farm boundaries, fallows, roadsides, and crop under-story, to meet planned and opportunistic fodder needs; or in a companion role, they can be sown as grass-legume pasture to satisfy long-term feed requirements (Lenné and Wood 2004; Peters et al. 2001).
Tropical forage biomass is usually an intermediate product primarily aiming at increasing livestock productivity. In addition to increasing milk and meat production, they can also contribute to other production objectives such as reducing risks in the face of feed scarcity, increasing yields of associated food crops through weed suppression, pest and disease reduction (in rotations or as intercrop), and increased manure quantity and quality for crop fertilization (Peters et al. 2001; White et al. 2013). Tropical forage technologies are also reported to have environmental cobenefits, including soil rehabilitation and soil quality improvement. Forage grasses can increase carbon accumulation through their deep-rootedness and perennial nature. Forage legumes can improve soil fertility through nitrogen fixation, and increase water efficiency through deep reaching taproots. Pioneering species such as Stylosanthes spp. have the potential to rehabilitate severely degraded land. Grasses, legumes, and trees/shrubs, when planted as hedgerows, cover crops, or live barriers, can reduce soil erosion and runoff (Rao et al. 2015; Schultze-Kraft et al. 2018). Climate change mitigation can be achieved through increased carbon accumulation particularly in deeper soil layers, reduced methane emission intensity from enteric fermentation through higher nutritional value and digestibility of feed, lower nitrous oxide emissions from soils through biological nitrification inhibition (BNI) capacities of selected grasses, and increase of aboveground carbon through integration of fodder trees in silvopastoral systems (Peters et al. 2013). The potential, multidimensional benefits of improved forages in smallholder systems in SSA are summarized in Fig. 1.

Research on tropical forages in SSA has been spread over time and regions. Yet a comprehensive, quantitative overview of forage technologies, as well as ranges and magnitudes of their multidimensional impacts, is currently lacking. This study aims to take stock of the state of forage research in SSA by conducting a systematic, quantitative literature review with the following objectives: (i) provide an overview of geographical distribution and forage technology focus of past research; (ii) quantify magnitudes of impacts of tropical forage technologies on forage productivity and quality, livestock productivity, soil quality, economic performance and food crop productivity at plot, animal and household level; and (iii) present the variability of forage agronomy data.

\section{Materials and methods}

\subsection{Literature search and study selection}

We performed a systematic literature search in June 2016 to compile peer-reviewed articles. We used the scientific search engine Scopus, employing the following search terms: "livestock", "feeds" OR "forage" OR "fodder", and "Africa". We 


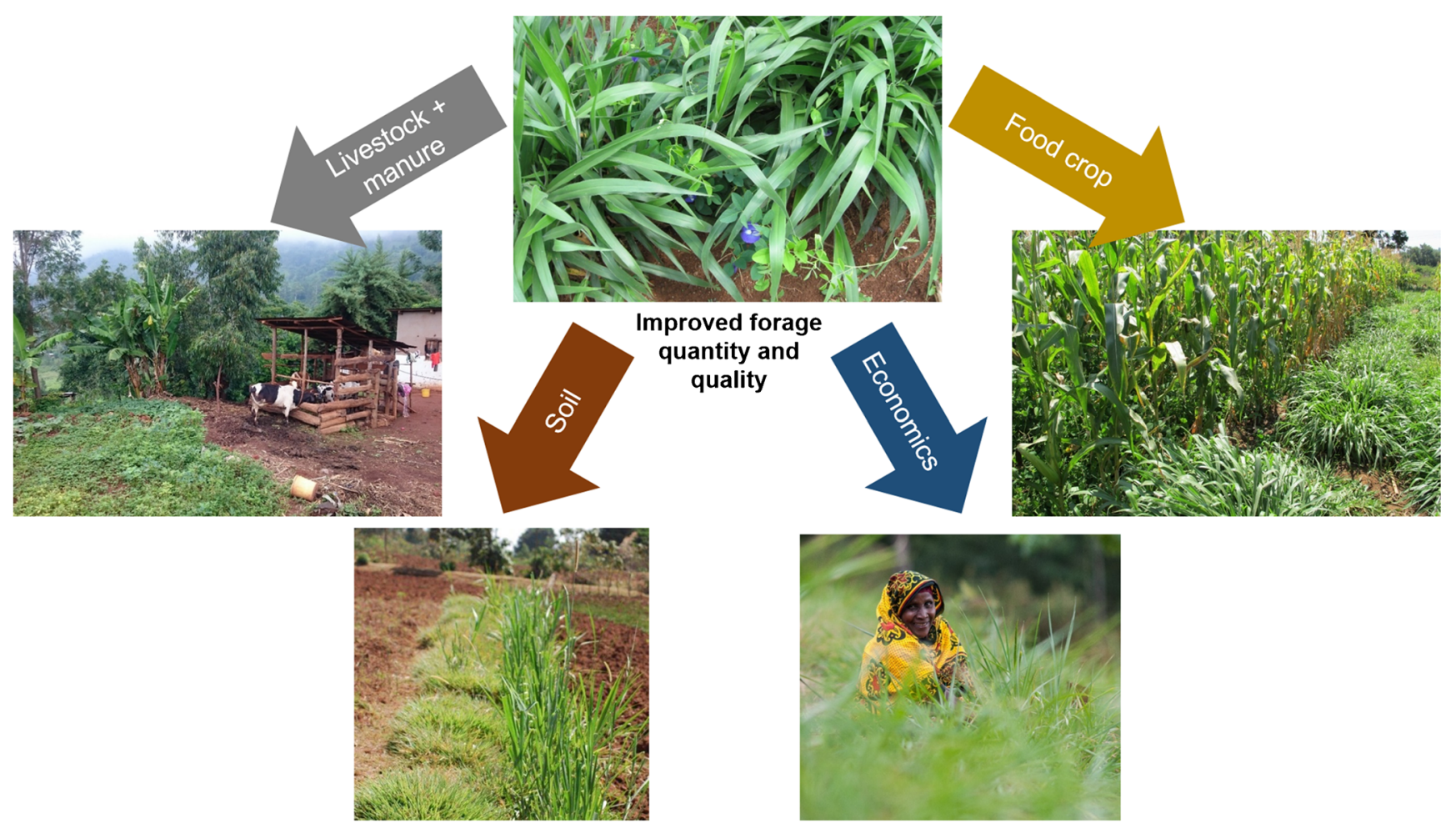

Fig. 1 Improved tropical forage technologies have been promoted for use in smallholder systems in Sub-Saharan Africa (SSA) for their potential multiple benefits: increased herbage productivity and better nutritive quality, leading to increased livestock productivity (meat, milk,

complemented this search with references cited in the primary literature and unpublished studies obtained from the authors' personal networks. For inclusion into this review, we only selected studies that met the following criteria: (1) The study reported empirically measured, original data on one of the target impact indicators (see section 2.2), excluding simulated data or data cited in reviews or secondary articles; (2) the article examined at least one tropical forage technology (grass, herbaceous or dual-purpose legume, leguminous multipurpose trees, and shrubs hereafter called "shrubs") but not cereal crop residues, concentrates or tree products - if the technology was a dual-purpose legume, it was only included if the forage or livestock impact was assessed as well; (3) the article focused on ruminant livestock, excluding monogastrics; (4) the study reported data from experimental, "improved" treatments and a control treatment; (5) the reported data was continuous and numerical thus not reported in scores, ranks, percentages or as graphs; (6) the study was written in English; (7) basic experimental information was available in section 2; and (8) the study was conducted in Sub-Sahara Africa. Using these criteria, 72 studies were found suitable to be included in the review (see references of review). These studies were published over 30 years between 1985 and 2015 (Fig. 2a). For each of the 107 experimental sites across the 72 studies, we extracted the reported geographical location. If precise geographical coordinates were not reported in the publication, we manure), soil quality (erosion, carbon, nutrients), economic performance of the household, and food crop productivity (grains and stover). Photo credits: B.K. Paul (forages, livestock + manure, soil), G. Smith, CIAT (economics) and B.L. Maass (food crop)

chose the center of the lowest-level known administrative unit and added GPS coordinates extracted from Google maps. We mapped the dominant livestock production system of all study locations (Robinson et al. 2011) (Fig. 2b).

\subsection{Forage technologies, impact dimensions, and data retrieval}

Forage technologies were classified as follows: (a) Germplasm referring to newly introduced forages (i. grass; ii. herbaceous legume; iii. dual-purpose legume) that were tested in on-station or on-farm trials against a local control forage; (b) Management comprising (i) fertilization regimes (mineral fertilizer and manure) and (ii) planting method such as manure application in planting holes, and compared treatment performance to the farmers' practices; (c) Cropping system integration describing (i) forage grass and/or shrub planted as hedgerow with food crops, (ii) forage grass, legume, and/or shrub intercropped with food crop, or (iii) forage grass intercropped with forage legume; (d) Feeding regime including the supplementation of basal feed like residues or grasses with leguminous forages, fed as either fresh biomass, or vines, haulms, hay or leaf meal — forages can be (i) herbaceous legume, (ii) dual-purpose legume, or (iii) shrub (Table 1). Throughout this study, we are using the scientific names of forages under which the studies were published 
a

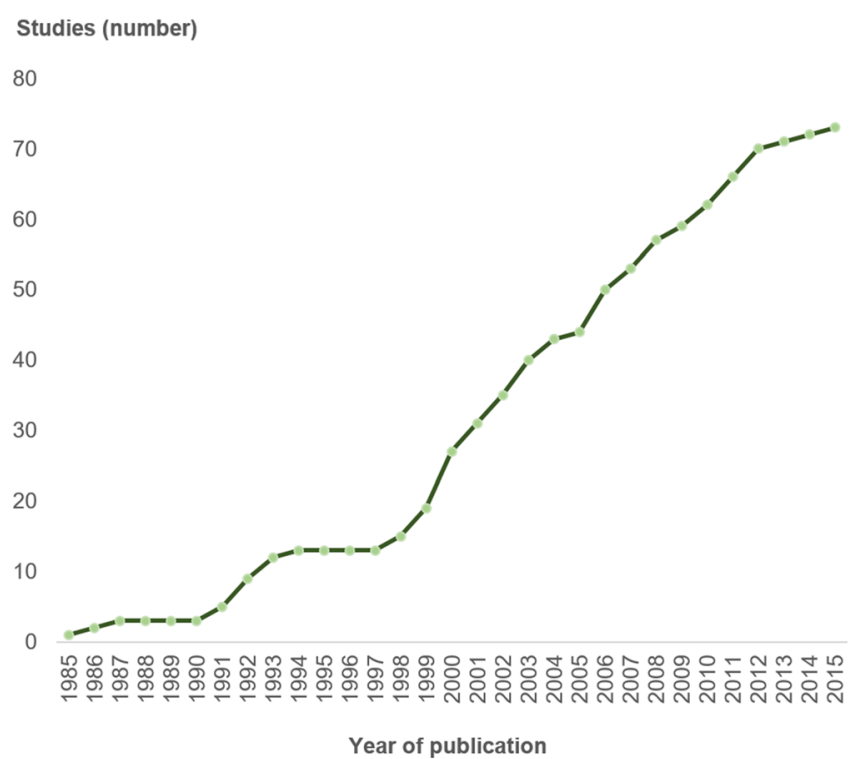

Fig. 2 Cumulative number of studies included in this review per publication year (a), and the 107 experimental study sites from all studies mapped on dominant livestock production systems across SSA (Robinson et al. 2011) (b). The studies were obtained through a systematic search of peer-reviewed literature in 2016, which was complemented with references cited in primary literature and unpublished studies obtained for the authors' personal networks. Using seven selection criteria, 72 studies were found suitable to be included in

despite the fact that many important species have recently changed, e.g., all Brachiaria spp. to Urochloa spp., Napier grass (Pennisetum purpureum) to Cenchrus purpureus, and Panicum maximum to Megathyrsus maximus, among many more (Cook and Schultze-Kraft 2015).

Effects of forage technologies on five impact dimensions were considered, which loosely follow the economic, social, and environmental domains outlined in White et al. (2013) and Rao et al. (2015): (i) forage productivity and qualityherbage dry matter (DM) yield, crude protein (CP), and metabolizable energy (ME) contents; (ii) livestock productivity - milk yield, dry matter intake (DMI), manure production, and nitrogen $(\mathrm{N})$ content in manure; (iii) soil quality - soil loss (SL), soil organic carbon (SOC); (iv) household economics - revenue and benefit; and (v) food crop productivity - grain and stover yields. Data was extracted from the 72 selected papers into a Microsoft Access database. In addition to impacts, we extracted experimental and technology descriptions including type of technology and forage species, cropping system, management, and number of replications $(\mathrm{N})$. Figure 3 summarizes the number of studies and pairs of observations (treatment - control) per impact dimension and indicator (columns) and technology groups (rows) that are reported in this review. Improved germplasm effects b

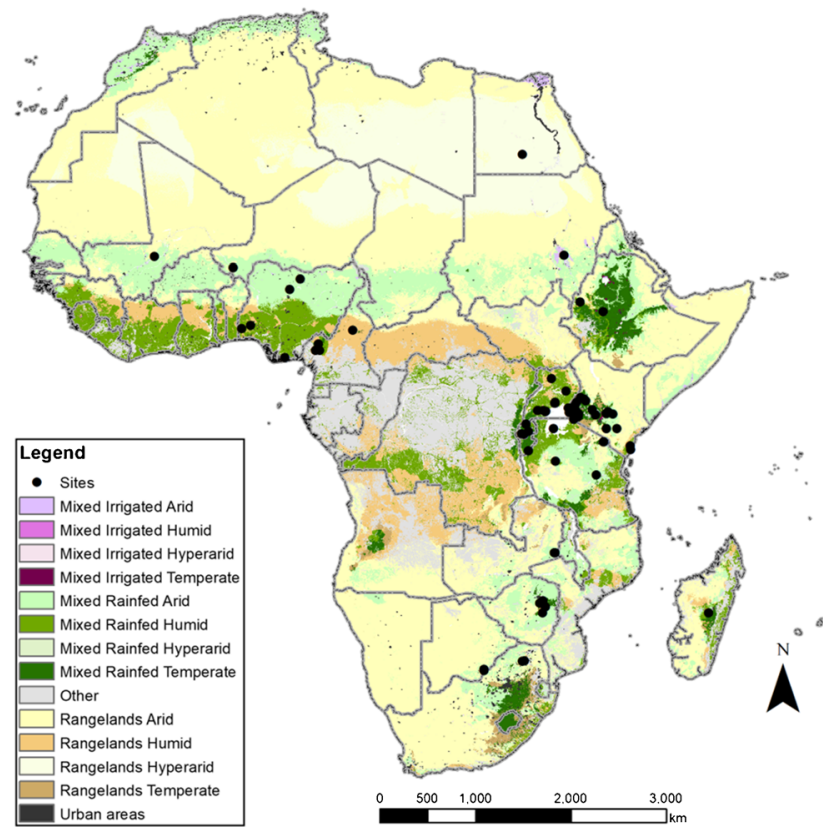

the review, published since 1985. If geographical coordinates were not reported in the publication, we chose the center of the lowest-level known administrative unit and added GPS coordinates extracted from Google maps. Studies were conducted across 15 countries in SSA, most of which in East Africa (49). Most sites were located in the mixed rainfed croplivestock zones (24 sites humid, 23 sites tropical highlands/temperate), and only five sites in rangeland areas (four arid, one hyperarid)

on forage productivity and quality, cropping system integration effects on soil quality, household economics, and food crop productivity were shown as overall average impacts as well as by technology subgroup (plain color). The technologies falling under improved management and cropping system integration were considered to be too diverse to be presented as average impact values across all technologies. Effects of improved management and cropping system integration on forage productivity were only shown as average impacts by technology subgroup (striped pattern). Results were calculated from a total of 780 pairs of observations (Fig. 3).

\subsection{Data analysis}

We used methods such as weighted response ratios from the field of metaanalysis (Hedges et al. 1999) to quantify magnitudes of effects of tropical forage technologies on forage productivity and quality, livestock productivity, soil quality, economic performance, and food crop productivity. Similar to Delaquis et al. (2018), the breadth of technologies and effects included in the study, and the lack of quality of reported agronomic data (e.g., failure to report variance), resulted in a lack of directly comparable measures, indicators, and variables. Therefore, this study could not take a complete 
Table 1 Forage technology groups and forage species included in the review. The scientific names of forages under which the studies were published are used despite recent name changes (i.e., Brachiaria spp. to Urochloa spp., Pennisetum purpureum to Cenchrus purpureus, and
Panicum maximum to Megathyrsus maximus in the grasses; Centrosema pubescens to C. molle and Pueraria phaseoloides to Neustanthus phaseoloides in the legumes) following Cook and Schultze-Kraft (2015)

\begin{tabular}{lll}
\hline Technology & $\begin{array}{l}\text { Technology } \\
\text { subgroup }\end{array}$ & Forage species \\
\hline
\end{tabular}

a) Germplasm: Newly introduced forage germplasm- $\quad$ i Grass compared with local species as control

\begin{tabular}{|c|c|}
\hline i Grass & $\begin{array}{l}\text { Brachiaria brizantha/B. hybrids/B. decumbens, Pennisetum } \\
\text { purpureum }\end{array}$ \\
\hline $\begin{array}{l}\text { ii Herbaceous } \\
\text { legume }\end{array}$ & $\begin{array}{l}\text { Stylosanthes guianensis, Centrosema macrocarpum/C. } \\
\text { pubescens, Pueria phaseoloides, Mucuna pruriens, } \\
\text { Desmodium heterocarpon-ovalifolium, Zornia glabra, } \\
\text { Dioclea guianensis, Arachis pintoi, Aeschynomene histrix, } \\
\text { Flemingia macrophylla }\end{array}$ \\
\hline $\begin{array}{l}\text { iii Dual-purpose } \\
\text { legume }\end{array}$ & Vigna unguiculata \\
\hline i Fertilizer & $\begin{array}{l}\text { Pennisetum purpureum, Lablab purpureus, Desmodium } \\
\text { uncinatum, Mucuna pruriens, Stylosanthes scabra, } \\
\text { Macroptilium atropurpureum }\end{array}$ \\
\hline ii Planting method & Pennisetum purpureum \\
\hline $\begin{array}{l}\text { i Grass/shrub } \\
\text { hedgerow with } \\
\text { food crop }\end{array}$ & $\begin{array}{l}\text { Pennisetum purpureum, Calliandra calothyrsus, Leucaena } \\
\text { leucocephala/L. diversifolia, Sesbania sesban }\end{array}$ \\
\hline $\begin{array}{l}\text { ii } \\
\text { Grass/legume/sh- } \\
\text { food crop }\end{array}$ & $\begin{array}{l}\text { Desmodium uncinatum/D. intortum, Pennisetum purpureum, } \\
\text { Chloris gayana, Vigna unguiculata, Lablab purpureus, } \\
\text { Stylosanthes fruticosa/S. hamata, Mucuna pruriens, Clitoria } \\
\text { ternata, Cajanus cajan, Vigna trilobata, Gliricidia sepium, } \\
\text { Sesbania sesban }\end{array}$ \\
\hline $\begin{array}{l}\text { iii Grass-legume } \\
\text { association }\end{array}$ & $\begin{array}{l}\text { Desmodium uncinatum/D. intortum, Pennisetum purpureum, } \\
\text { Brachiaria spp, Arachis pintoi, Stylosanthes scabra/S. } \\
\text { guianensis, Macroptilium atropurpureum, Panicum } \\
\text { maximum, Clitoria ternatea, Tripsacum laxum, Setaria } \\
\text { splendida, Macrotyloma axillare, Centrosema molle }\end{array}$ \\
\hline $\begin{array}{l}\text { i Herbaceous } \\
\text { legume }\end{array}$ & $\begin{array}{l}\text { Desmodium intortum, Canavalia ensiformis, Centrosema } \\
\text { macrocarpum, Macroptilium atropurpureum, Neontonia } \\
\text { wightii, Stylosanthes scabra/S. guianensis, Mucuna pruriens, } \\
\text { Medicago sativa, Aeschynomene histrix }\end{array}$ \\
\hline $\begin{array}{l}\text { ii Dual-purpose } \\
\text { legume }\end{array}$ & $\begin{array}{l}\text { Arachis pintoi, Cajanus cajan, Lablab purpureus, Vigna } \\
\quad \text { unguiculata }\end{array}$ \\
\hline iii Shrub & $\begin{array}{l}\text { Calliandra calothyrsus, Leucaena leucocephala, Gliricidia } \\
\text { sepium, Sesbania sesban, Colospermum mopane }\end{array}$ \\
\hline
\end{tabular}

Brachiaria brizantha/B. hybrids/B. decumbens, Pennisetum pubescens, Pueria phaseoloides, Mucuna pruriens, Flemingia macrophylla

Pennisetum purpureum, Lablab purpureus, Desmodium uncinatum, Mucuna pruriens, Stylosanthes scabra,

Pennisetum purpureum Pennisetum purpureum, Calliandra calothyrsus, Leucaena esmodium uncinatum/D. intortum, Pennisetum purpureum Stylosanthes fruticosa/S. hamata, Mucuna pruriens, Clitoria ternata, Cajanus cajan, Vigna trilobata, Gliricidia sepium, esmodium uncinatum $/ D$. intortum, Pennisetum purpureum, Brachiaria spp, Arachis pintoi, Stylosanthes scabra/S. sis, Macroptilium atropurpureum, Panicum maximum, Clitoria ternatea, Tripsacum laxum, Setaria esmodium intortum, Canavalia ensiformis, Centrosema wightii, Stylosanthes scabra/S. guianensis, Mucuna pruriens,

Calliandra calothyrsus, Leucaena leucocephala, Girt
sepium, Sesbania sesban, Colospermum mopane b) Management: Improved agronomic measures applied to forage dual purpose and herbaceous legumes and grasses compared to same crop without improved agronomy as control

c) Cropping system integration: Forage dual purpose and herbaceous legumes, grasses and shrubs are combined with food crops as hedgerow or intercrop, and forage legume and grass intercropped - compared to same situation without combination as control

d) Feeding regime: Supplementation of basal diet with improved, mostly leguminous forages as fresh biomass, vines, haulms, hay or leaf meal - compared to basal diet as control metaanalysis approach fulfilling all the criteria laid out by Philibert et al. (2012), including analyzing the heterogeneity of data with random-effect models, sensitivity analysis, and investigation of publication bias.

We quantified the effect of forage technologies on the impact indicators (see section 2.2) calculating response ratios (RR) for individual observations:

$$
R R=\left(\frac{X_{E}}{X_{C}}\right)
$$

where $X_{E}$ is the impact indicator value for the forage technology treatment, and $X_{C}$ is the impact indicator value for the control treatment.
For most observations in our dataset, the original studies did not report measures of variance. Consequently, we relied on a nonparametric approach to weighing observations instead of using the inverse of the pooled variance. Effect sizes were weighed by replication to assign more weight to wellreplicated studies:

$W_{R}=\frac{N_{C} * N_{E}}{\left(N_{C}+N_{E}\right)}$

where $W_{R}$ is the weighing factor by replication, $N_{C}$ the number of treatments per control, and $N_{E}$ the number of replicates per experimental treatment. If no $N$ was reported for a study, $N=1$ was assumed.

Multiple observations from the same field site or several treatments with only one control are not independent, and this 


\begin{tabular}{|c|c|c|c|c|c|c|c|c|c|c|c|c|c|}
\hline \multirow[b]{2}{*}{ Technology } & \multirow[b]{2}{*}{ Sub-group } & \multicolumn{3}{|c|}{$\begin{array}{l}\text { Forage } \\
\text { productivity and } \\
\text { quality }\end{array}$} & \multicolumn{4}{|c|}{ Livestock productivity } & \multicolumn{2}{|c|}{ Soil quality } & \multicolumn{2}{|c|}{$\begin{array}{l}\text { Household } \\
\text { economics }\end{array}$} & \multirow{2}{*}{\begin{tabular}{|l}
$\begin{array}{c}\text { Food crop } \\
\text { productivity }\end{array}$ \\
Grain Stov \\
\end{tabular}} \\
\hline & & DM & $\mathrm{CP}$ & ME & Milk & DMl & Man & Man N & SL & SOC & $\operatorname{Rev}$ & Ben & \\
\hline Germpla sm & $\begin{array}{l}\text { i. Grass } \\
\text { ii. Herbaceous legume } \\
\text { iii. Dual-purpose legume }\end{array}$ & $\begin{array}{l}2 / 25 \\
1 / 2 \\
1 / 6\end{array}$ & $1 / 18$ & & & & & & & & & & \\
\hline Management & $\begin{array}{l}\text { i. Fertilizer } \\
\text { ii. Planting method }\end{array}$ & 614 & yxty & & & & & & & & & & \\
\hline $\begin{array}{l}\text { Cropping system } \\
\text { integration }\end{array}$ & $\begin{array}{l}\text { i. Grass/shrub hedgerow with food crop } \\
\text { ii. Grass/legume/shrub intercrop with food crop } \\
\text { iii. Grass-legume association }\end{array}$ & 1168 & 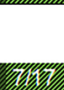 & visusy & & & & & $4 / 74$ & $\begin{array}{l}1 / 5 \\
1 / 9\end{array}$ & $6 / 43$ & $\begin{array}{l}1 / 4 \\
4 / 38 \\
\end{array}$ & \begin{tabular}{|l|l|}
$4 / 80$ & \\
$13 / 182$ & $3 / 40$ \\
\end{tabular} \\
\hline Feeding regime & $\begin{array}{l}\text { i. Herbaceous legume } \\
\text { ii. Dual-purpose legume } \\
\text { iii. Shrub }\end{array}$ & & & & $\begin{array}{l}5 / 14 \\
5 / 6 \\
5 / 14\end{array}$ & $\begin{array}{l}6 / 15 \\
4 / 6 \\
5 / 9 \\
\end{array}$ & $2 / 3$ & $\begin{array}{l}1 / 2 \\
2 / 3\end{array}$ & & & & & \\
\hline
\end{tabular}

Fig. 3 Number of studies and pairs of observations (treatment-control) of this review reported in brackets. Impact dimensions and indicators are listed in columns, and technology groups in rows. Results were calculated from a total of 780 pairs of observations. Colors differentiate impact dimensions: forage productivity and quality (green shades), improved feeding regime on livestock productivity (grey shades), improved cropping system integration on soil quality (red shades), household economics (blue shades), and food crop productivity (brown shades).

needs to be accounted for in the weights. To avoid bias, the weighing factor by replication was, thus, further divided by the number of measurements and treatments:

$W_{o}=\frac{W_{R} / T}{M}$

where $W_{o}$ is the overall weighing factor per observation, $W_{R}$ is the weighing factor by replication, $T$ the number of treatments per respective control, and $M$ the number of measurements per treatment. This ensured that all experimental comparisons in multifactor and multiyear studies could be included in the data set without dominating the overall effect size.

Mean effect sizes for the overall sample and per technology type were estimated as follows:

$\overline{R R}=\frac{\sum\left(R R_{i} * W_{O i}\right)}{\sum W_{O i}}$

With $R R_{i}$ being the effect size of the $i$ th comparison, and $W_{O i}$ the overall weighing factor for the $i$ th comparison.

Standard errors were calculated. Indicator units differed between studies, but standardization was not considered necessary for computation of response ratios.

\section{Results and discussion}

\subsection{Geographical distribution of research and characterization of forage technologies}

Analyzing the retrieved studies in terms of their geographical locations, technologies, and impact dimensions aimed to
Germplasm effects on forage productivity and quality, cropping system integration effects on soil quality, household economics, and food crop productivity were shown as overall average impacts (see Fig. 4) as well as by technology subgroup (see Fig. 5) (plain color). Effects of improved management and cropping system integration on forage productivity were only shown as average impacts by technology subgroup (see Fig. 5) (striped pattern)

reveal and explain focus of past research. The 72 experimental studies included in the review were published between 1985 and 2015, with a peak in the period from 1999 to 2007 (Fig. 2a). Studies were conducted in 15 countries. Within East Africa (49 studies), most studies reported results from Kenya (29). Nine studies were conducted in West Africa, nine in Southern Africa, and five in Central Africa. Most sites were located in the rainfed mixed crop-livestock zones (24 sites humid/subhumid, 23 sites tropical highlands/temperate), and only five sites in rangeland areas (four arid/semiarid, one hyperarid) (Fig. 2b). Studies included a wide variety of forage grasses, legumes, and shrubs (Table 1).

Distinct differences in forage technology research focus per region become apparent. Planted grasses (mainly Pennisetum purpureum and Brachiaria spp.) and multipurpose shrubs (Calliandra spp., Leucaena spp., and to a lesser extent Sesbania) dominate past research in East Africa, including their intercropping with food crops (maize, and to a lesser extent sorghum and millet) and hedgerow cropping of fodder shrubs and grasses with maize and soybean, and wheat and beans. In West Africa, herbaceous legumes (mainly Stylosanthes spp., Desmodium spp., Mucuna pruriens) and dual-purpose legumes (mainly Lablab purpureus and Vigna unguiculata) research has been most prominent. Perennial intercropped herbaceous legumes were undersown or relay-planted, and often allowed to grow throughout the following season(s) as improved fallow. Only a few experimental studies from Southern Africa were identified. Four of the nine total studies were conducted in Botswana, and focused either on leguminous shrubs or forage legumes, with only one study on forage grass-legume association (Brachiaria hybrid cv. Mulato and Arachis pintoi) (Table 1; References of the metaanalysis). 
The regional differences in amount of studies and specific species reflect the different production systems, agroecologies as well as presence of research centers. The International Livestock Research Institute (ILRI), the International Center for Tropical Agriculture (CIAT), and the International Center for Agricultural Research in the Dry Areas (ICARDA) and regional networks have been leading the international forage research in SSA over the last 30 years, with a focus on breeding and germplasm evaluation. In the national agricultural research systems (NARS), programs were established in the 1960s and 1970s to test and adapt novel forage species and superior genotypes. In the 1990s, a strong movement started towards participatory research to match varietal characteristics with needs and interests of smallholder livestock keepers (Boonman 1993; Hall et al. 2007; Stür et al. 2013). The focus on temperate, humid, and subhumid areas might be explained with higher perceived chances of success of planted forages in mixed croplivestock systems. Pastoral communities, often concentrating in arid and semi-arid regions, are unlikely to invest in new forages for communally grazed pastures until joint grazing management strategies are in place (Nyariki and Ngugi 2002). There tends to be cultural reluctance to grow forages if producers are unfamiliar with the concept of investing labor for planting, management, and harvesting, as well as capital for seeds and land for feed that was previously "for free". Such investment is mostly common for food crops but not for feed (Thomas and Sumberg 1995).

The advancement of Kenya's dairy industry has been largely based on the wide-spread use of Pennisetum purpureum (Pengelly et al. 2003) which has been extensively researched by ILRI and national partners. Its high biomass production with equally high water and soil fertility requirements made it suitable to sub-humid, high-potential highland systems where land availability is limited due to high population pressure. The World Agroforestry Center (ICRAF) and partners promoted agroforestry with multipurpose shrubs and trees with a focus on cut-and-carry systems in eastern Africa. Calliandra calothyrsus is most commonly planted as it is fast growing and tolerant to frequent cuttings. However, it is not as nutritious as other species including Leucaena leucocephala and L. trichandra, and Sesbania sesban. Key advantages include that they require little land, and contributions to firewood and erosion control (Place et al. 2009; Franzel et al. 2014).

In West Africa, Stylosanthes guianensis and S. hamata (Stylo), Mucuna pruriens (Mucuna), Centrosema pascuorum, and Aeschynomene histrix have been promoted for use in fodder banks and improved fallows by ILRI and its national partners. These technologies aimed to alleviate feed stress of agropastoralists in subhumid zones, especially during the long dry season. For a large part of the dry season, a fodder bank planted with herbaceous legumes close to the homestead can maintain a crude protein content of $9 \%$ compared with $<7 \%$ of the naturally available pastures during that time. Those legumes can also increase subsequent crop yields on the same plot due to nitrogen fixation and improvement of physical soil quality. Stylo has been introduced and promoted since the late 1970s, and Mucuna since the late 1980s (Elbesha et al. 1999; Tarawali et al. 1999). Dual-purpose cowpea (Vigna unguiculata) is another crop that has been developed and promoted for mixed crop-livestock systems in the dry savannah zones of West Africa by ILRI and the International Institute for Tropical Agriculture (IITA). Various dual-purpose cowpea varieties have been developed and tested that can deliver benefits on household food productivity, livestock feed, soil quality, and nutrient cycling. Improved dual-purpose cowpea varieties could replace traditional varieties that have been used to either produce grain or fodder (Kristjanson et al. 2002, 2005; Lenné et al. 2003; Tarawali et al. 2003). However, it is important to note that focus on literature published in English has led to a bias against francophone literature from West and Central Africa.

\subsection{Magnitudes of multidimensional effects of forage technologies}

Calculating average technology effects on selected indicators aimed to quantify the multidimensional impacts of tropical forages on forage productivity and quality, livestock productivity, soil quality, economic performance, and food crop productivity at plot, animal, and household level.

Most studies reported data on only one impact dimension, while it was studies on improved cropping system integration that assessed several dimensions such as forage productivity, soil quality, and food crop productivity (Fig. 3). In a global review of forage impact studies, White et al. (2013) also found that only few studies included various impact dimensions and tradeoffs.

A total of 233 observations reported impacts of forage technologies on forage productivity and quality (Fig. 3). Average herbage productivity of improved forage germplasm technologies was 2.65 times higher than the local controls, and CP content $18 \%$ higher (Fig. 4). When differentiating forage productivity impacts by technology groups, introducing improved forage germplasm had the largest effect. Grass germplasm exhibited on average three times higher herbage yield than the local control, followed by herbaceous legumes with almost doubling herbage productivity, and dual-purpose legumes with $27 \%$ higher yield (Fig. 5a). Fertilizer application and planting method increased average herbage productivity by $21 \%$ and $7 \%$, respectively (Fig. 5 b). Associating a forage grass with a legume increased average total herbage productivity by $49 \%$ and almost doubled CP content of the overall forage when compared with a grass only, while ME remained almost equal (Fig. 5c). 


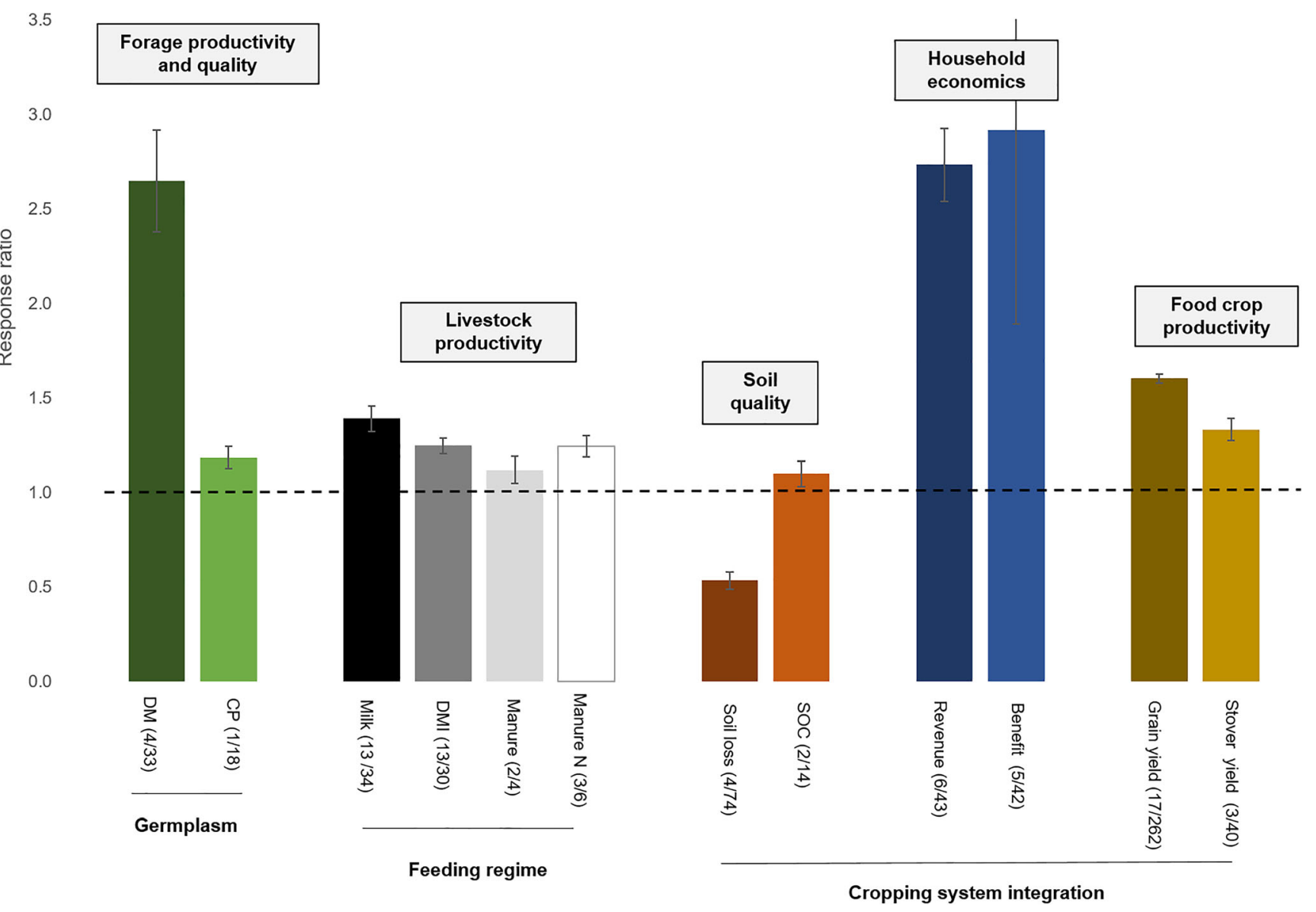

Fig. 4 Weighed mean response ratios with standard error for overall effects of technologies on indicators across the five impact dimensions. Mean effects of improved germplasm on forage productivity and quality (green shades), improved feeding regime on livestock productivity (grey shades), improved cropping system integration on soil quality (red

Impacts of improved feeding regimes with forages on livestock productivity were measured and reported by 72 observations, all focusing on legume interventions (Fig. 3). Overall, they improved milk yield by an average of $39 \%$, dry matter intake (DMI) by $25 \%$, nitrogen content of manure by $24 \%$, and manure quantity by $12 \%$ when compared with the basal diets (Fig. 4). When separating impacts by technology subgroups, herbaceous legumes had the largest average effect on milk yield, increasing productivity by $47 \%$. Herbaceous legumes also had the largest effect on DMI, higher than dualpurpose legumes or multipurpose trees and shrubs (Fig. 5d).

Studies also measured effects of tropical forages on soil quality, household economics, and food crop productivity. A total of 88 observations reported effects of forage integration in cropping systems on soil quality, 85 observations on household economics, and 302 observations on food crop yields (Fig. 3). Integrating planted forages into cropping systems overall almost halved soil loss, and increased SOC by an average of $10 \%$. On average, they almost tripled economic revenue and benefit, and increased crop grain yields by $60 \%$ and

shades), household economics (blue shades), and food crop productivity (brown shades). The dashed line indicates a response ratio of 1 , which is the threshold for increase $(>1)$ or decrease $(<1)$ when compared with the control. Number of studies and observations are reported in brackets

stover yields by $33 \%$ (Fig. 4). When separating impacts by technology subgroups, it becomes apparent that associating a forage grass or legume with a food crop was more profitable than hedgerow cropping, more than tripling economic benefit and resulted in 75\% higher food crop yields (Fig. 5c).

Improved forage grasses can fill persistent feed gaps in terms of quantity more easily than forage legumes. Overall, forage grasses have been a more important research area than fodder legumes in Africa in the past 100 years (Boonman 1993; Lenné and Wood 2004). However, in many rainfed smallholder farming systems, it is not only the quantity and quality of forage produced that matter, but particularly their seasonality. Especially in drier areas, dry-season feed availability can become more important than overall herbage production (Ates et al. 2018). Relative dry-season feed productivity still remains understudied despite its widely recognized importance.

Changes in milk production are an often-measured response to feed improvements. Dairy animals are frequently used to assess improved forage quality as it translates rapidly 


\section{a. Germplasm}

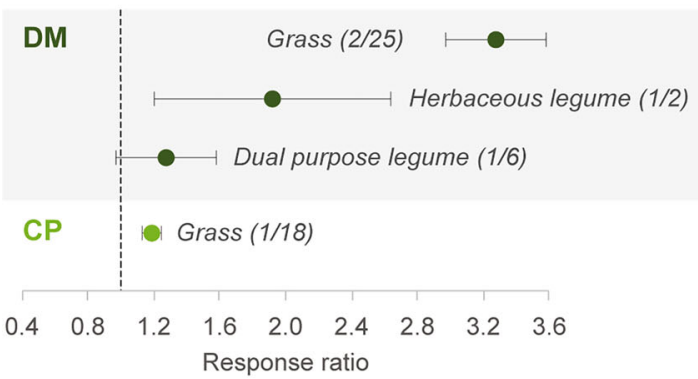

\section{b. Management}

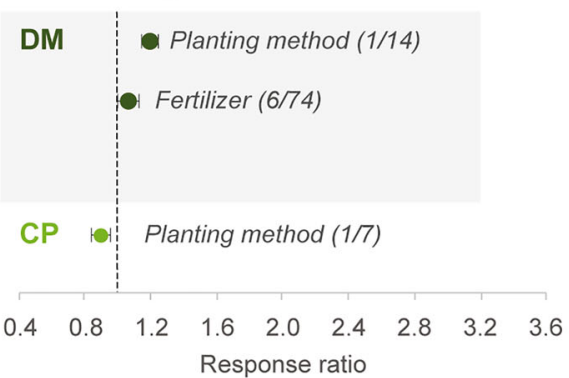

\section{c. Cropping system integration}

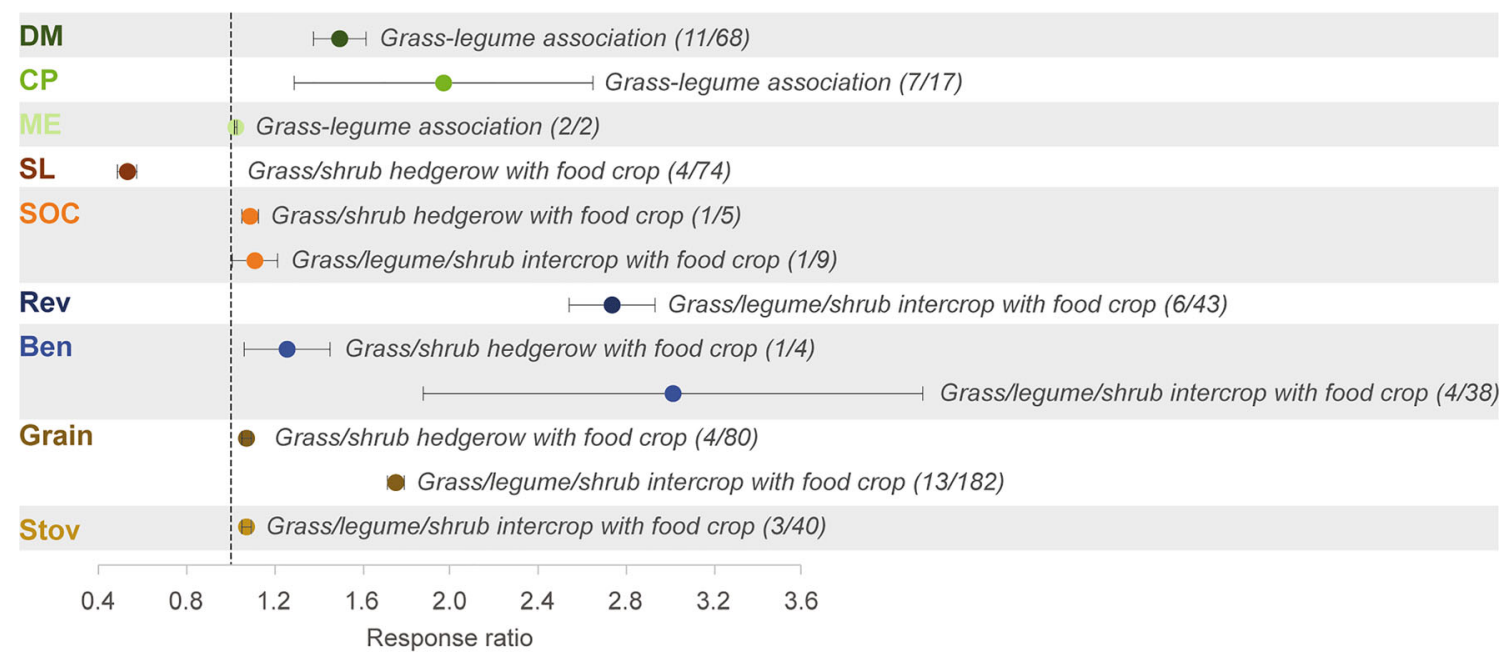

\section{d. Feeding regime}

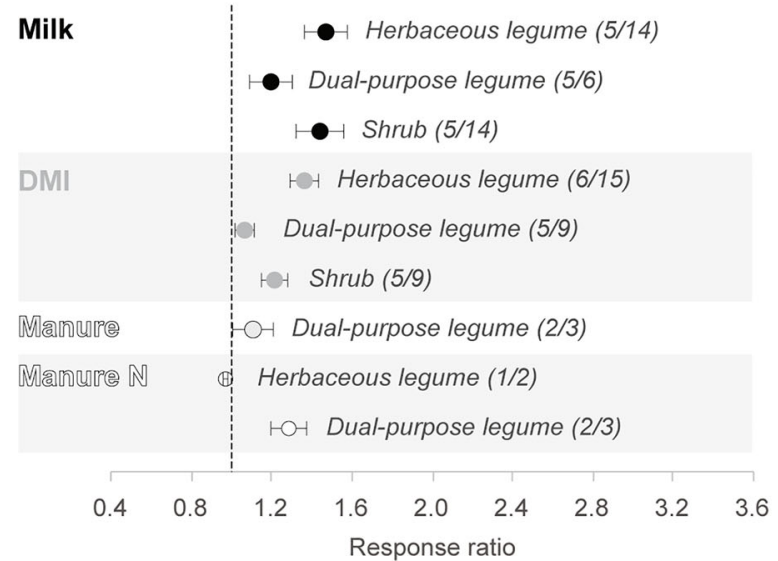

Fig. 5 Weighed mean response ratios with standard error for effects of technology subgroups on indicators across the five impact dimensions. Germplasm subtechnology effects on forage productivity and quality (a), management sub-technology effects on forage productivity and quality (b), cropping system integration subtechnology effects on soil quality, household economics and food crop productivity (c), and feeding regime sub-technology effects on livestock productivity (d). Color

into higher milk yield as long as the cows have sufficient genetic potential (Lascano 2001). However, costs of feeding trials involving animals are more resource-intensive to shades are used to indicate impact dimensions: green for forage productivity and quality, grey for livestock productivity, red for soil quality, blue for household economics and brown for food crop productivity. The dashed line demarcates a response ratio of 1 , which is the threshold for increase $(>1)$ or decrease $(<1)$ when compared with the control. Number of studies and observations are reported in brackets

conduct, partly explaining the relatively lower amount of observations on livestock productivity impacts when compared with other impact dimensions. The lower magnitude of 
impacts from livestock feeding regimes when compared with forage productivity points to the fact that higher quantity and quality of feed does not directly translate into livestock productivity response as several other factors such as current nutritional status of the animals, animal health, breed, and management practices might be limiting productivity. A combination of interventions is often necessary, including improved animal breeds, husbandry, and health to reach desired productivity responses (Van De Ven et al. 2003).

Forage integration into cropping systems has often been highlighted as key to deliver multiple benefits to farmers, yet there are only few successful and published examples (Maass et al. 2015; Paul et al. 2020). Various studies focused on Desmodium spp. and mostly referred to the push-pull system in which the pest control factor has an additional effect on food crop yields (Hassanali et al. 2008a). Hedgerow cropping with fodder shrubs could lead to competition and lower food crop yields, depending on the exact agronomic arrangement and agroecological conditions. Variability was high in the economic data, which was also reported by Franzel et al. (2014) for fodder shrub hedgerow cropping. Net return in Kenya and Uganda varied widely, depending on the number of trees grown on the farm, the amount of supplementation with leaf meal, and the milk prices, which can vary between locations and seasons and influence profitability. Inconsistent valuation methods and assumptions further complicated the economic comparisons, e.g., full costs are often not reported, which corroborates with findings by White et al. (2013).

The analysis suggests that tropical forages can deliver multiple benefits to smallholder farmers, although few studies investigated multiple effects simultaneously. Planted forages are uniquely positioned at a crossroads between various disciplines - agronomy, animal nutrition, and environmental sciences - linking crop, livestock, and soil components of farming systems (Paul et al. 2020). Understanding whole system implications of forage introduction into a farming system is required-e.g., for estimating trade-offs in labor requirement or food security when intensifying livestock production (Ates et al. 2018; Paul et al. 2020). In fact, farmers seem to make decisions based on balancing or satisfying multiple objectives, instead of optimizing one single objective - which has been coined "satisficing behavior" (van Kooten et al. 1986; Simon 1957). Farming systems research and wholefarm economic analysis to evaluate benefits and risks, can provide decision support to farmers as well as evidence for researchers and funding agencies to prioritize (research) investments (Pengelly et al. 2003). There is a need for more comprehensive, multidisciplinary studies taking farming system approaches to assess the attractiveness of multiple benefits of forage technologies, depending on specific locations, opportunities, production objectives, and constraints.

\subsection{Variability of forage productivity}

Lastly, this review aimed to assess and present the variability of forage agronomy data. Absolute forage grass yield figures across studies were highly variable (Table 2). Herbage DM yields for Pennisetum purpureum ranged from 0.25 to $37.3 \mathrm{t} / \mathrm{ha}$ with most values around 3 $10 \mathrm{t} / \mathrm{ha}$, with the lowest value recorded in a semiarid environment per season. Crude protein contents for Pennisetum purpureum reached as much as $16.3 \%$ in an experiment in Kitale, Kenya, while most other figures varied between 5 and $8 \%$ (Table 2).

The high variability in forage agronomic performance in terms of biomass productivity is remarkable which might be explained by two reasons. Firstly, Napier grass is native to SSA and adapted to a wide range of soil and agroecological conditions from 0 to $2100 \mathrm{~m}$ above sea level, as well as annual rainfall between 750 and $2500 \mathrm{~mm}$ (Negawo et al. 2017). However, yields can vary widely, depending on the cultivar grown, and its interactions with agroclimatic conditions and management. Globally, some studies have even reported yields of up to $66 \mathrm{t} \mathrm{DM} / \mathrm{ha} /$ year in Malaysia, $78 \mathrm{t} \mathrm{DM} / \mathrm{ha} /$ year in Brazil or $90 \mathrm{t} \mathrm{DM/ha/year} \mathrm{in} \mathrm{Zimbabwe} \mathrm{(Negawo} \mathrm{et} \mathrm{al.}$ 2017), which is significantly more than the ranges reported for SSA in this review. Similarly, the CP content of Napier grass is significantly influenced by cutting treatments and intervals, and fertilization (Negawo et al. 2017). The choice of experimental control and fertilization regime might also explain some of the observed variability. Secondly, despite various international efforts (e.g., Tarawali et al. 1995; 't Mannetje 2000), the research field and methods of forage agronomy are not standardized, also due to the comparably less research that has taken place as compared to food crops. Forage biomass productivity is assessed in various ways in terms of establishment time, cutting interval, cutting height, and reporting times (per harvest, season, year). This made results less comparable across sites and studies.

There is a need in SSA for implementing both proposed standards in forage agronomy, and capacity building in forage agronomy. However, investment in forage research has been low, with for example only seven forage agronomists out of the 545 agricultural scientists in Kenya (Murithi and Minayo 2011). Further statistical analysis of the heterogeneity of forage productivity data could identify explanatory variables for the observed site-year variability, relying on additional metaanalysis methods such as random-effects models and sensitivity analysis as proposed by Philibert et al. (2012). Moreover, crop yields observed in studies under controlled conditions, such as on-station experimental trials, are likely greater than those obtained in uncontrolled on-farm situations where the interplay of factors determines yields. It is well 
Table 2 Forage grass biomass yields and crude protein contents for Pennisetum purpureum, Brachiaria spp. and Panicum maximum. The scientific names of the grasses under which the studies were published are used despite recent name changes (Brachiaria spp to Urochloa spp., Pennisetum purpureum to Cenchrus purpureus, and Panicum maximum to Megathyrsus maximus) following Cook and Schultze-Kraft (2015)

\begin{tabular}{|c|c|c|c|c|c|c|c|}
\hline Reference & Country & Site & Improved forage crop & $\begin{array}{l}\text { Herbage } \\
\text { yield }\end{array}$ & Unit herbage & $\begin{array}{l}\text { CP content (\% of } \\
\mathrm{DM})\end{array}$ & Unit CP \\
\hline Barahenda et al. 2007 & Rwanda & Huye & Pennisetum purpureum & 15.3 & $\mathrm{t} \mathrm{DM} / \mathrm{ha} / 16$ months & & \\
\hline Kabirizi et al. 2013 & Uganda & Masaka & Pennisetum purpureum & 10.35 & $\begin{array}{l}\mathrm{t} \mathrm{DM} / \mathrm{ha} / 24 \\
\text { months }\end{array}$ & 7 & $\begin{array}{l}\% \text { of } \\
\text { DM }\end{array}$ \\
\hline Kabirizi et al. 2015 & Uganda & Masaka & Pennisetum purpureum & 10.35 & t DM/ha/year & 7 & $\begin{array}{l}\% \text { of } \\
\mathrm{DM}\end{array}$ \\
\hline Kabirizi 2009 & Uganda & Masaka & Pennisetum purpureum & 10.02 & t DM/ha/year & 7.4 & $\begin{array}{l}\% \text { of } \\
\mathrm{DM}\end{array}$ \\
\hline Katuromunda et al. 2011 & Uganda & Makerere & Pennisetum purpureum & 5.61 & tha & & \\
\hline Kawube et al. 2014 & Uganda & Namulonge & Pennisetum purpureum & 4.03 & $\mathrm{t}$ & & \\
\hline Kawube et al. 2014 & Uganda & Namulonge & Pennisetum purpureum & $3.65-6.28$ & $\mathrm{t}$ & & \\
\hline $\begin{array}{l}\text { Mureithi and Thorpe, } \\
2000\end{array}$ & Kenya & Mtwapa & Pennisetum purpureum & 26.2 & t DM/ha/year & & \\
\hline Muyekho et al. 2000 & Kenya & Moiben & Pennisetum purpureum & $5.6-10.8$ & t DM/ha/year & 11.5 & $\begin{array}{l}\% \text { of } \\
\text { DM }\end{array}$ \\
\hline Muyekho et al. 2000 & Kenya & Kitale & Pennisetum purpureum & $22.9-37.3$ & t DM/ha/year & 16.3 & $\begin{array}{l}\% \text { of } \\
\mathrm{DM}\end{array}$ \\
\hline Niang et al. 1998 & Rwanda & Bubereka & Pennisetum purpureum & 26.7 & $\begin{array}{l}\mathrm{kg} \mathrm{DM} / \mathrm{m} / 48 \\
\text { months }\end{array}$ & 11.3 & $\begin{array}{l}\% \text { of } \\
\text { DM }\end{array}$ \\
\hline Njarui 2007 & Kenya & Katumani & Pennisetum purpureum & $0.25-4.35$ & t DM/ha/season & & \\
\hline Ruto et al. 2000 & Kenya & Keiyo & Pennisetum purpureum & 8.2 & t DM/ha/4 cuts & & \\
\hline $\begin{array}{l}\text { Mutimura and Everson } \\
2012\end{array}$ & Rwanda & Bugesera & $\begin{array}{l}\text { Brachiaria brizantha } \\
\text { cultivars }\end{array}$ & $4.58-5.71$ & t DM/ha/harvest & $4.92-6.41$ & $\begin{array}{l}\% \text { of } \\
\text { DM }\end{array}$ \\
\hline $\begin{array}{l}\text { Mutimura and Everson } \\
2012\end{array}$ & Rwanda & Bugesera & $\begin{array}{l}\text { Brachiaria decumbens } \\
\text { cultivars }\end{array}$ & $4.79-5.61$ & t DM/ha/harvest & $6.69-7.74$ & $\begin{array}{l}\% \text { of } \\
\text { DM }\end{array}$ \\
\hline $\begin{array}{l}\text { Mutimura and Everson } \\
2012\end{array}$ & Rwanda & Bugesera & Brachiaria hybrids & $2.63-5.13$ & t DM/ha/harvest & $4.34-8.91$ & $\begin{array}{l}\% \text { of } \\
\text { DM }\end{array}$ \\
\hline $\begin{array}{l}\text { Mutimura and Everson } \\
2012\end{array}$ & Rwanda & Nyamagabe & $\begin{array}{l}\text { Brachiaria brizantha } \\
\text { cultivars }\end{array}$ & $4.18-4.47$ & t DM/ha/harvest & & \\
\hline $\begin{array}{l}\text { Mutimura and Everson } \\
2012\end{array}$ & Rwanda & Nyamagabe & $\begin{array}{l}\text { Brachiaria decumbens } \\
\text { cultivars }\end{array}$ & $3.72-4.57$ & t DM/ha/harvest & & \\
\hline $\begin{array}{l}\text { Mutimura and Everson } \\
2012\end{array}$ & Rwanda & Nyamagabe & Brachiaria hybrids & $1.32-5.95$ & t DM/ha/harvest & & \\
\hline Njwe et al. 1992 & Cameroon & Dschang & Brachiaria ruziziensis & 1.79 & t DM/ha/year & 113 & $\mathrm{~kg} / \mathrm{ha}$ \\
\hline Njarui 2007 & Kenya & Katumani & Panicum maximum & $0.15-5.62$ & t DM/ha/season & & \\
\hline
\end{tabular}

documented that only a small proportion of farmers will reach the average yield under on-station experimentation, owing to the large variability of agro-ecological conditions and management that affect performance. New statistical methods can help to further understand the high on-farm agronomic variability (Vanlauwe et al. 2016).

\section{Conclusions}

Quantitative reviews are key to summarizing evidence on what is known, synthesizing it for use within or outside of the research domain, and formulating future research priorities. To the best of our knowledge, this review for the first time: (i) takes stock of geographical distribution and forage technologies of past research in SSA; (ii) quantifies the range and magnitude of multidimensional effects of forage technologies including livestock productivity, soil quality, household economics, and food crop productivity; and (iii) presents variability in forage agronomy data.

Major findings of this review include the following: (1) Most studies focused on only one impact dimension, most frequently forage and food crop productivity, and only cropping system integration studies reported benefits across dimensions; (2) Improved forage germplasm had on average 2.65 higher herbage production than local controls, with strongest effect in grasses; (3) Crude protein of the overall forage doubled when grasses and legumes were grown in 
association; (4) Feeding regimes that include improved leguminous forages increased milk yield by on average $39 \%$, dry matter intake by $25 \%$, and manure production by $24 \%$; (5) When forage technologies were integrated with food crops, soil loss was almost halved, soil organic carbon increased on average by $10 \%$, and grain and stover yields by $60 \%$ and $33 \%$, respectively; (6) Variability in the findings from forage agronomy was high.

Further research is needed to explore and explain agronomic variability of forage production. Deployment of additional, statistical metaanalysis techniques could assess site-year variability, and identify relevant explanatory variables (Philibert et al. 2012). Further, it is well-known that agronomic performance and effect sizes may differ between on-station and onfarm experimentation, with the former achieving higher yields due to a variety of factors including better soil quality and management. New statistical methods can help to further understand on-farm agronomic variability, and unravel interactions between genotype, management, and environment effects (Vanlauwe et al. 2016). Such understanding is also needed to inform technology dissemination to ensure higher and more stable performance under heterogeneous smallholder production environments.

Tropical forages can deliver multiple benefits to smallholder farmers, especially when integrated into cropping systems. Therefore, they can play a central role in sustainably intensifying crop-livestock systems in SSA, which has been suggested before (e.g., Ates et al. 2018). Multidimensional impacts of technologies become increasingly recognized as key, also for integration in farming systems and adoption. For example, in the discussions around Climate-Smart Agriculture (CSA) and Sustainable Intensification (SI), concepts of synergies and tradeoffs between various objectives become more and more important (Campbell et al. 2014). Satisfying such multidimensional objectives simultaneously is also suggested to be key to farmers' adoption of technologies (van Kooten et al. 1986; Simon et al. 1957). Adoption of tropical forage technologies, and underlying drivers and barriers, and incentives and enabling environment required to achieve impact at scale, deserves accelerated research attention. Tropical forages are an excellent case to explore and demonstrate the crucial need for multidisciplinary research on multidimensional impacts and tradeoffs technologies that are key to advance mixed crop-livestock systems (Paul et al. 2020). There is a need for more comprehensive, multidisciplinary studies taking farming system approaches to assess the attractiveness of multiple benefits of forage technologies, depending on specific locations, opportunities, production objectives, and constraints.

Results from this study can guide development priority setting and investments by synthesizing and taking stock of past research. They can inform the design of development programs, prioritizing technologies proven successful for dissemination in the region, and indicating magnitudes of impacts that could be expected from the interventions.

Acknowledgements This paper has benefitted from various contributions: John Yumbya Mutua (CIAT) for mapping the study sites, Celine Birnholz, Jessica Mukiri, and Alex Nduah (CIAT) for database and reference checks, Kees-Jan van Groenigen for advice on metaanalysis methods, Di Prestwidge (CSIRO) for help with database management and queries with Microsoft Access, and José Luis Urrea Benitez (CIAT) for assistance in figure design and format. We thank two anonymous reviewers and the editor for constructive comments that helped to substantially improve the manuscript.

Authors' contribution Conceptualization BKP, BLM, MP, JCJG, and PT; Data curation JK, AN, and BKP; Methodology BKP; Formal analysis BKP and JK; Visualization BKP; Writing - original draft BKP; Writing review and editing BKP, BLM, JK, AN, MP, JCJG, and PT; Funding acquisition $\mathrm{BKP}$ and $\mathrm{AN}$.

Funding information This study was financially supported by a United States Agency for International Development (USAID) linkage grant, and a small grant from the German Federal Ministry for Economic Cooperation and Development (BMZ)/Deutsche Gesellschaft für Internationale Zusammenarbeit (GIZ) (Contract C-151-15). This work was implemented as part of the CGIAR Research Program on Livestock, which is carried out with support from CGIAR Fund Donors and through bilateral funding agreements.

Data availability Data will be published on Harvard Dataverse.

\section{Compliance with ethical standards}

Conflict of interest The authors declare that they have no conflict of interest.

Open Access This article is licensed under a Creative Commons Attribution 4.0 International License, which permits use, sharing, adaptation, distribution and reproduction in any medium or format, as long as you give appropriate credit to the original author(s) and the source, provide a link to the Creative Commons licence, and indicate if changes were made. The images or other third party material in this article are included in the article's Creative Commons licence, unless indicated otherwise in a credit line to the material. If material is not included in the article's Creative Commons licence and your intended use is not permitted by statutory regulation or exceeds the permitted use, you will need to obtain permission directly from the copyright holder. To view a copy of this licence, visit http://creativecommons.org/licenses/by/4.0/.

\section{References}

't Mannetje L (2000) Measuring biomass of grassland vegetation. In: 't Mannetje L, Jones RM (eds) Field and laboratory methods for grassland and animal production research. CABI Publishing/CAB International, Wallingford, pp 151-177. https://doi.org/10.1079/ 9780851993515.0151

Ates S, Cicek H, Bell LW, Norman HC, Mayberry DE, Kassam S, Hannaway DB, Louhaichi M (2018) Sustainable development of smallholder crop-livestock farming in developing countries. In: IOP Conference Series: Earth and Environmental Science 142 (1): 
012076. IOP Publishing. https://doi.org/10.1088/1755-1315/142/1/ 012076

Ayele S, Duncan A, Larbi A, Khanh TT (2012) Enhancing innovation in livestock value chains through networks: lessons from fodder innovation case studies in developing countries. Sci Public Policy 39(3): 333-346. https://doi.org/10.1093/scipol/scs022

Bebe BO, Udo HMJ, Thorpe, W (2008) Characteristics of feeding and breeding practices for intensification of smallholder dairy systems in the Kenya Highlands. Livestock Research for Rural Development 20 (2), Article \#23 (URL: https://1rrd.cipav.org.co/lrrd20/2/ bebe20023.htm).

Boonman JG (1993) East Africa's grasses and fodders: Their ecology and husbandry. Kluwer Academic Publishers, Dordrecht. https://doi.org/ 10.1007/978-94-015-8224-7

Campbell BM, Thornton P, Zougmore R, van Asten P, Lipper L (2014) Sustainable intensification: what is its role in Climate Smart Agriculture? Curr Opin Environ Sustain 8:39-43. https://doi.org/ 10.1016/j.cosust.2014.07.002

Cook BG, Schultze-Kraft R (2015) Botanical name changes - nuisance or a quest for precision? Trop Grasslands-Forrajes Tropicales 3:34-40. https://doi.org/10.17138/tgft(3)34-40

Delaquis E, de Haan S, Wyckhuys KAG (2018) On-farm diversity offsets environmental pressures in tropical agro-ecosystems: a synthetic review for cassava-based systems. Agric Ecosyst Environ 251(2): 226-235. https://doi.org/10.1016/j.agee.2017.09.037

Elbesha E, Thornton PK, Tarawali G (1999) An ex-post economic impact assessment of planted forages in West Africa. Impact Assessment Series, Vol. 2. ILRI (International Livestock Research Institute), Nairobi, Kenya.

Franzel S, Carsan S, Lukuyu B, Sinja J, Wambugu C (2014) Fodder trees for improving livestock productivity and smallholder livelihoods in Africa. Curr Opin Environ Sustain 6:98-103. https://doi.org/10. 1016/j.cosust.2013.11.008

Hall A, Sulaiman R, Bezkorowajnyj P. (2007) Reframing technical change: livestock fodder scarcity revisited as innovation capacity scarcity. A Conceptual Framework. ILRI, ICRISAT, IITA, UNUMERIT.

Hassanali A, Herren H, Khan ZR, Pickett JA, Woodcock CM (2008a) Integrated pest management: the push-pull approach for controlling insect pests and weeds of cereals, and its potential for other agricultural systems including animal husbandry. Philos Trans R Soc B: Biological Sciences 363(1491):611-621. https://doi.org/10.1098/ rstb.2007.2173

Hedges LV, Gurevitch J, Curtis PS (1999) The meta-analysis of response ratios in experimental ecology. Ecology 80(4):1150-1156. https:// doi.org/10.2307/177062

Herrero M, Thornton PK, Notenbaert AM, Wood S, Msangi S, Freeman HA, Bossio D, Dixon J, Peters M, van de Steeg J, Lynam J, Rao PP, Macmillan S, Gerard B, McDermott J, Sere C, Rosegrant M (2010) Smart investments in sustainable food production: revisiting mixed crop-livestock systems. Science 327(5967):822-825. https://doi. org/10.1126/science.1183725

Herrero M, Havlik P, Valin H, Notenbaert A, Rufino MC, Thornton PK, Blummel M, Weiss F, Grace D, Obersteiner M (2013) Biomass use, production, feed efficiencies, and greenhouse gas emissions from global livestock systems. Proc Natl Acad Sci (PNAS) 110(52): 20888-20893. https://doi.org/10.1073/pnas.1308149110

Homann Kee-Tui SH, Valbuena D, Masikati P, Descheemaeker K, Nyamangara J, Claessens L, Erenstein O, van Rooyen A, Nkomboni D (2014) Economic trade-offs of biomass use in croplivestock systems: exploring more sustainable options in semi-arid Zimbabwe. Agric Syst 134:48-60. https://doi.org/10.1016/j.agsy. 2014.06.009

Kristjanson P, Tarawali S, Okike I, Singh BB, Thornton PK, Manyong VM, Kruska RL, Hoogenboom G (2002) Genetically improved dual-purpose cowpea: assessment of adoption and impact in the dry Savannah of West Africa. Impact Assessment Series No. 9. ILRI (International Livestock Research Institute), Nairobi, Kenya.

Kristjanson P, Okike I, Tarawali S, Singh BB, Manyong VM (2005) Farmers' perceptions of benefits and factors affecting the adoption of improved dual-purpose cowpea in the dry savannas of Nigeria. Agric Econ 32:195-210. https://doi.org/10.1111/j.0169-5150.2005. 00338.x

Lascano CE (2001) Animal production in grass-legume pastures in the tropics. In: Sotomayor-Rios A, Pitman WD (eds) Tropical Forage Plants: Development and Uses. CRC Press, Boca Raton, pp 219 232

Lenné JM, Wood D (2004) Is there a 'logic of fodder legumes' in Africa? Food Policy 29:565-585. https://doi.org/10.1016/j.foodpol.2004. 07.012

Lenné JM, Fernandez-Rivera S, Blümmel M (2003) Approaches to improve the utilization of food-feed crops - synthesis. Field Crop Res 84:213-222. https://doi.org/10.1016/s0378-4290(03)00136-9

Maass BL, Midega CAO, Mutimura M, Rahetlah VB, Salgado P, Kabirizi JM, Khan ZR, Ghimire SR, Rao IM (2015) Homecoming of brachiaria: improved hybrids prove useful for African Animal Agriculture. East Afr Agr For J 81(1):71-78. https://doi.org/10. 1080/00128325.2015.1041263

Murithi F, Minayo C (2011) Staff aging, turnover in African Agricultural Research. In: A case study on Kenya Agricultural Research Institute in: Agricultural R\&D: Investing in Africa Future. Analyzing trends, Challenges and opportunities. IFPRRI-FARA Conference, Ghana. URL: https://www.asti.cgiar.org/pdf/conference/Theme2/ CaseStudies/Murithi.pdf accessed 2 May 2019

Negawo A, Teshome A, Kumar A, Hanson J, Jones C (2017) Opportunities for Napier grass (Pennisetum purpureum) improvement using molecular genetics. Agronomy 7(2):28. https://doi.org/ 10.3390/agronomy 7020028

Nyariki DM, Ngugi RK (2002) A review of African pastoral production systems: approaches to their understanding and development. J Hum Ecol 13(3):237-250. https://doi.org/10.1080/09709274.2002. 11905539

Paul BK, Groot JCJ, Maass BL, Notenbaert AMO, Herrero M, Tittonell PA (2020) Improved feeding and forages at a crossroads: farming systems approaches for sustainable livestock development in East Africa. Outlook on Agr. https://doi.org/10.1177/ 0030727020906170

Pengelly BC, Whitbread A, Mazaiwana PR, Mukombe N (2003) Tropical forage research for the future-better use of research resources to deliver adoption and benefits to farmers. Tropical Grasslands 37(4):207-216

Peters M, Horne P, Schmidt A, Holmann F, Kerridge PC, Tarawali SA, Schultze-Kraft R, Lascano C, Argel P, Stur W, Fujisaka S, MullerSamann K, Wortmann C (2001) The role of forages in reducing poverty and degradation of natural resources in tropical production systems. AgREN Network Paper No. 117, ODI Agricultural Research and Extension Network.

Peters M, Herrero M, Fisher M, Erb K, Rao I, Subbarao GV, Castro A, Arango J, Chara J, Murgueito E, van der Hoek R, Laderach P, Hyman G, Tapasco J, Strassburg B, Paul B, Rincon A, SchultzeKraft R, Fonte S, Searchinger T (2013) Challenges and opportunities for improving eco-efficiency of tropical forage-based systems to mitigate greenhouse gas emissions. Tropical Grasslands - Forrajes Tropicales 1:156-167

Philibert A, Loyce C, Makowski D (2012) Assessment of the quality of meta-analysis in agronomy. Agric Ecosyst Environ 148:72-82. https://doi.org/10.1016/j.agee.2011.12.003

Place F, Roothaert R, Maina L, Franzel S, Sinja J, Wanjiku J (2009) The impact of fodder trees on milk production and income among smallholder dairy farmers in East Africa and the role of research. Occasional Paper 12, World Agroforestry Center (ICRAF), Nairobi, Kenya. 
Rao I, Peters M, Castro A, Schultze-Kraft R, White D, Fisher MJ, Lascano C, Blummel M, Bungenstab D, Tapasco J, Hyman G, Bolliger A, Paul B, van der Hoek R, Maass BL, Tiemann T, Cuchillo M, Douxchamps S, Villanueva C, Rincon A, Avarza M, Rosenstock T, Subbarao G, Arango J, Cardoso JA, Worthington M, Chrinda N, Notenbaert A, Jenet A, Schmidt A, Vivas N, Lefroy R, Fahrney K, Guimaraes E, Tohme J, Cook M, Herrero M, Chacon M, Searchinger T, Rudel T (2015) LivestockPlus - the sustainable intensification of forage-based agricultural systems to improve livelihoods and ecosystem services in the tropics. Tropical Grasslands Forrajes Tropicales 3(2):59

Robinson TP, Thornton PK, Franceschini G, Kruska RL, Chiozza F, Notenbaert A, Cecchi G, Herrero M., Epprecht M, Fritz S, You L, Conchedda G, and See L (2011) Global livestock production systems. Rome, Italy: Food and Agriculture Organization of the United Nations (FAO) and Nairobi, Kenya: International Livestock Research Institute (ILRI), 1-152.

Rudel TK, Paul B, White D, Rao IM, van der Hoek R, Castro A, Boval M, Lerner A, Schneider L, Peters M (2015) LivestockPlus: forages, sustainable intensification, and food security in the tropics. Ambio 44:685-693. https://doi.org/10.1007/s13280-015-0676-2

Schultze-Kraft R, Rao IM, Peters M, Clements RJ, Bai C, Liu G (2018) Tropical forage legumes for environmental benefits: an overview. Tropical Grasslands-Forrajes Tropicales 6(1):1-14. https://doi.org/ $10.17138 / \operatorname{tgft}(6) 1-14$

Simon HA (1957) Models of Man: Social and Rational. John Wiley \& Sons, New York

Stür W, Khanh TT, Duncan A (2013) Transformation of smallholder beef cattle production in Vietnam. Int J Agric Sustain 11(4):363-381. https://doi.org/10.1080/14735903.2013.779074

Tarawali SA, Tarawali G, Larbi A, Hanson J (1995) Methods for the evaluation of forage legumes, grasses and fodder trees for use as livestock feed, 1st edn. ILRI (International Livestock Research Institute), Nairobi

Tarawali G, Manyong VM, Carsky RJ, Vissoh PV, Osei-Bonsu P, Galiba M (1999) Adoption of improved fallows in West Africa: lessons from Mucuna and stylo studies. Agrofor Syst 47:93-122. https:// doi.org/10.1023/A:1006270122255

Tarawali SA, Singh BB, Gupta SS, Tabo R, Harris F, Nokoe S, Fernandez-Rivera S, Bationo A, Manyong VM, Makinde K, Odion EC (2003) Cowpea as a key factor for a new approach to integrated crop-livestock systems research in the dry savannas of West Africa. In: Challenges and opportunities for enhancing sustainable cowpea production, 4-7 September 2000, (International Institute for Tropical Agriculture (IITA), Ibadan, Nigeria.

Thomas D, Sumberg JE (1995) A review of the evaluation and use of tropical forage legumes in sub-Saharan Africa. Agric Ecosyst Environ 54(3):151-163. https://doi.org/10.1016/0167-8809(95) 00584-f

Tittonell P, Gérard B, Erenstein O (2015) Tradeoffs around crop residue biomass in smallholder crop-livestock systems - what's next? Agric Syst 134:119-128. https://doi.org/10.1016/j.agsy.2015.02.003

Valbuena D, Erenstein O, Homann-Kee Tui S, Abdoulaye T, Claessens L, Duncan AJ, Gerard B, Rufino MC, Teufel N, van Rooyen A, van Wijk MT (2012) Conservation Agriculture in mixed crop-livestock systems: scoping crop residue trade-offs in Sub-Saharan Africa and South Asia. Field Crop Res 132:175-184. https://doi.org/10.1016/j. fcr.2012.02.022

Van De Ven GWJ, De Ridder N, Van Keulen H, van Ittersum MK (2003) Concepts in production ecology for analysis and design of animal and plant-animal production systems. Agric Syst 76(2):507-525. https://doi.org/10.1016/s0308-521x(02)00110-5

Van Kooten GC, Schoney RA, Hayward KA (1986) An alternative approach to the evaluation of goal hierarchies among farmers. West $\mathrm{J}$ Agric Econ 11(1):40-49
Vanlauwe B, Coe R, Giller KE (2016) Beyond averages: new approaches to understand heterogeneity and risk of technology success or failure in smallholder farming. Exp Agric 55(S1):84-106. https://doi.org/ $10.1017 / \mathrm{s} 0014479716000193$

White DS, Peters M, Horne P (2013) Global impacts from improved tropical forages: a meta-analysis revealing overlooked benefits and costs, evolving values and new priorities. Tropical Grasslands Forrajes Tropicales 1:12-24. https://doi.org/10.17138/tgft(1)12-24

\section{References of the meta-analysis}

Akinlade J, Smith JW, Raji A, Busari A, Adekunle I, Adewumi M (2005) Effect of two cowpea (Vigna unguiculata) fodder cultivars as supplements on voluntary intake; milk yield and manure production of Bunaji cows. J Agric Rural Dev Trop Subtrop 106(2):105-112 URL: https://jarts.info/index.php/jarts/article/view/87

Angima S, Stott DE, O’Neill MK, Ong CK, Weesies GA (2002) Use of Calliandra-Napier grass contour hedges to control erosion in central Kenya. Agric Ecosyst Environ 91(1-3):15-23. https://doi.org/10. 1016/S0167-8809(01)00268-7

Ayoub A (1986) The potential contribution of some forage crops to the Nitrogen budget and animal feed in the Sudan Gezira farming system. In: Haque I, Jutzi S, Neatte P (eds) (1985) Potentials of forage legumes in farming systems of Sub-Saharan Africa: proceedings of a workshop held at ILCA, Addis Ababa, Ethiopia, 16-19 September 1985. URL: https://books.google.com/books?id=uW1Yfp1XgVsC

Barahenda M, Shem M, Kanuya N, Ntakabeza I, Gasana J, Uwimana G, Umenezero O, Uwumikuza D (2007) Yield potential of grasslegume pasture under different management systems. Research Journal of Animal Sciences 1(2):59-61 URL: http:// medwelljournals.com/abstract/?doi=rjnasci.2007.59.61

Boitumelo W, Mahabile W (1992) Improving milk production in smallscale dairy farms in Botswana: incorporating legume fodder in the farming systems. In: Stares JE et al. (eds) (1992): The complementarity of feed resources for Animal production in Africa.

De Groote H, Vanlauwe B, Rutto E, Odhiambo GD, Kanampiu F, Khan ZR (2010) Economic analysis of different options in integrated pest and soil fertility management in maize systems of Western Kenya. Agric Econ 41(5):471-482. https://doi.org/10.1111/j.1574-0862. 2010.00459.x

Gbaraneh LD, Ikpe FN, Larbi A, Wahua TA, Torunana J (2004) The influence of lablab (Lablab purpureus) on grain and fodder yield of maize (Zea mays) in a humid forest region of Nigeria. J Appl Sci Environ Manag 8(2):45-50. https://doi.org/10.4314/jasem.v8i2. 17239

Guto SN, Pypers P, Vanlauwe B, de Ridder N, Giller KE (2011) Tillage and vegetative barrier effects on soil conservation and short-term economic benefits in the Central Kenya highlands. Field Crop Res 122(2):85-94. https://doi.org/10.1016/j.fcr.2011.03.002

Hassanali A, Herren H, Khan ZR, Pickett JA, Woodcock CM (2008b) Integrated pest management: the push-pull approach for controlling insect pests and weeds of cereals, and its potential for other agricultural systems including animal husbandry. Philos Trans R Soc B: Biological Sciences 363(1491):611-621. https://doi.org/10.1098/ rstb.2007.2173

Hassen A, Gizachew L, Rethman NFG, Van Niekerk WA (2007) Influence of undersowing perennial forages in maize on grain, fodder yield and soil properties in the sub-humid region of western Ethiopia. Afr J Range Forage Sci 24(1):35-41. https://doi.org/10. 2989/102201107780178168

Kabirizi JML (2009) Participatory testing of forage legume innovations with women farmers in Masaka District, Uganda: Impact on fodder availability, animal performance and household income. In: Urama 
K et al. (2009) Agricultural Innovations for Sustainable Development, 2 (1): 79-84.

Kabirizi J, Mpairwe D, Mutetikka D (2006a) Improving dairy cattle productivity in smallholder farms in Uganda: Incorporating leguminous forages in farming systems. Uganda J Agric Sci 12(1):1-12

Kabirizi J, Mpairwe D, Mutetika D (2006b) Effect of intercropping forage legumes with elephant grass on fodder production in intensive smallholder dairy farms in Uganda. Uganda J Agric Sci 12(2):16-25

Kabirizi J, Taabu L, Kigongo J, Namazzi C, Ebiyau G, Oketayot J, Ogwal S (2010) The contribution of women to food and fodder production in war affected areas of Gulu District in Uganda. In: Proceedings of Second RUFORUM Biennial Regional Conference on "Building capacity for food security in Africa", Entebbe, Uganda, 20-24 September 2010 (pp. 1643-1653).

Kabirizi J, Ziiwa E, Mugerwa S, Ndikumana J, Nanyennya W (2013) Dry season forages for improving dairy production in smallholder systems in Uganda. Tropical Grasslands-Forrajes Tropicales 1(2):212214. https://doi.org/10.17138/tgft(1)212-214

Kabirizi J, Muyekho F, Mulaa M, Msangi R, Pallangyo B, Kawube G, Zziwa E, Mugerwa S, Ajanga S, Lukwago G, Wamalwa NIE, Kariuki I, Mwesigwa R, Nannyeenya-Ntege W, Atuhairwe A, Awalla J, Namazzi C, Nampijja Z (2015) Dry season forages for improving dairy production in smallholder systems in Uganda. Napier grass feed resource: production, constraints and implications for smallholder farmers in Eastern and Central Africa. EAAPP (The Eastern African Agricultural Productivity Project) Naivasha, Kenya.

Kakengi AM, Shem MN, Mtengeti EP, Otsyina R (2001) Leucaena leucocephala leaf meal as supplement to diet of grazing dairy cattle in semiarid Western Tanzania. Agrofor Syst 52(1):73-82. https:// doi.org/10.1023/A:1010642531865

Karachi M, Zengo M (1998) Legume forages from pigeon pea, leucaena and Sesbania as supplements to natural pastures for goat production in western Tanzania. Agrofor Syst (Netherlands). https://doi.org/10. 1023/A:1005859617603

Kariuki JN, Gitau GK, Gachuiri CK, Tamminga S, Muia JMK (1999a) Effect of supplementing napier grass with desmodium and lucerne on DM, CP and NDF intake and weight gains in dairy heifers. Livest Prod Sci 60(1):81-88. https://doi.org/10.1016/S0301-6226(99) 00035-4

Kariuki JN, Tamminga S, Gitau GK, Gachuiri CK, Muia JMK (1999b) Performance of Sahiwal and Friesian heifers fed on napier grass supplemented with graded levels of lucerne. S Afr J Anim Sci, 29 (1). https://doi.org/10.4314/sajas.v29i1.44220

Kariuki JN, Tamminga S, Gachuiri CK, Gitau GK, Muia JMK (2001) Intake and rumen degradation in cattle fed napier grass (Pennisetum purpureum) supplemented with various levels of Desmodium intortum and Ipomoea batatus vines. S Afr J Anim Sci 31(3):149 157. https://doi.org/10.4314/sajas.v31i3.3798

Katuromunda S, Sabiiti EN, Bekunda MA (2011) Effect of combined application of cattle manure and mineral fertilisers on the growth characteristics and quality of Pennisetum purpureum fodder. Livest Res Rural Dev 23(12):1-10 URL: http://lrrd.org/lrrd23/12/ katu23251.htm

Katuromunda S, Sabiiti EN, Bekunda AM (2012) Effect of legume foliage supplementary feeding to dairy cattle offered Pennisetum purpureum basal diet on feed intake and manure quality. Uganda $\mathrm{J}$ Agric Sci 13(1):25-34 URL: https://ajol.info/index.php/ujas/article/ view/12611

Kawube G, Alicai T, Otim M, Mukwaya A, Kabirizi J, Talwana H (2014) Resistance of Napier grass clones to Napier grass stunt disease. Afr Crop Sci J 22(3):229-236 URL: https://ajol.info/index.php/acsj/ article/view/107186

Khan ZR, Hassanali A, Overholt W, Khamis TM, Hooper AM, Pickett JA, Wahams L, Woodcock CM (2002) Control of witchweed Striga hermonthica by intercropping with Desmodium spp. and the mechanism defined as allelopathic. J Chem Ecol 28(9):18711885. https://doi.org/10.1023/A:1020525521180

Khan ZR, Midega CA, Amudavi DM, Hassanali A, Pickett JA (2008a) On-farm evaluation of the 'push-pull' technology for the control of stemborers and striga weed on maize in western Kenya. Field Crop Res 106(3):224-233. https://doi.org/10.1016/j.fcr.2007.12.002

Khan ZR, Midega CA, Njuguna EM, Amudavi DM, Wanyama JM, Pickett JA (2008b) Economic performance of the 'push-pull' technology for stemborer and Striga control in smallholder farming systems in western Kenya. Crop Prot 27(7):1084-1097. https://doi.org/ 10.1016/j.cropro.2008.01.005

Khan ZR, Midega CA, Wanyama JM, Amudavi DM, Hassanali A, Pittchar J, Pickett JA (2009) Integration of edible beans (Phaseolus vulgaris L.) into the push-pull technology developed for stemborer and Striga control in maize-based cropping systems. Crop Prot 28(11):997-1006. https://doi.org/10.1016/j.cropro.2009. 05.014

Kiflewahid B, Mosimanyana B (1987) Feeding of crop residues to milking cows in small scale farms in Botswana. In: Utilization of agricultural by-products as livestock feeds in Africa: proceedings of a workshop held in Blantyre, Malawi

Kouamé CN, Hoefs S, Powell JM, Roxas D, Renard CA (1991) Intercrop Stylosanthes effects on millet yields and animal performance in the Sahel. In: Stares John ES, Said AN, Kategile JA (eds) Joint Feed Resources Networks Workshop (1991, Gaborone, Botswana). The complementarity of feed resources for animal production in Africa. URL: https://cgspace.cgiar.org/handle/10568/49957

Kouamé CN, Powell JM, Renard CA, Quesenberry KH (1993) Plant yields and fodder quality related characteristics of millet-stylo intercropping systems in the Sahel. Agronomy Journal, 85 (3): 601-605. In: Shetty SV et al. (1995) Millet and cowpea in mixed farming systems of the Sahel: A review of strategies for increased productivity and sustainability. In: Powell et al. (1995) Livestock and sustainable nutrient cycling in mixed farming systems of SubSahara Africa, 2. https://doi.org/10.2134/agronj1993. $00021962008500030015 x$

Kusekwa ML, Kyamanyma RS, Ngowi MD (1992) Fitting forage legumes into the cropping systems of semi-arid Tanzania. In: Stares JE et al. (eds) (1991) The complementarity of feed resources for animal production in Africa. Proceedings of the joint feed resources networks workshop held in Gaborone, Botswana (pp. 215-221). URL: https://books.google.com/books?id=xjGVx-vPXBkC

Lanyasunya TP, Rong WH, Abdulrazak SA, Mukisira EA (2006) Effect of supplementation on performance of calves on smallholder dairy farms in Bahati division of Nakuru District, Kenya. Pak J Nutr 5(2): 141-146 https://doi.org/10.3923/pjn.2006.141.146

Macala J, Sebolai B, Majinda RR (1992) Colophospermum mopane browse plant and sorghum stover as feed resources for ruminants during the dry season in Botswana. In: Stares JE et al. (eds) (1992) Joint Feed Resources Network Workshop on the Complementarity of Feed Resources for Animal Production in Africa, Gaborone (Botswana), 4-8 Mar 1991. URL: https://books.google.co.ke/ books?id=xjGVx-vPXBkC\&pg=PA151\&lpg=PA151\&dq=

Mafongoya PL, Kuntashula E, Kwesiga F, Chirwa T, Chintu R, Sileshi G, Matibini J (2003) Leguminous agroforestry options for replenishing soil fertility in Southern Africa. In: Waddington SR (ed) (2003) Grain Legumes and Green Manures for Soil Fertility in Southern Africa: Taking Stock of Progress. Proceedings of a conference held 8-11 October 2002 in Vumba, Zimbabwe (p. 141). URL: https:// books.google.co.ke/books?id=x0bNhhtdUicC\&pg=PA141\&lpg= $\mathrm{PA} 141 \& \mathrm{dq}=$

Masinde AA, Okeyo RO, Ojowi MO, Oyure AO (2000) Evaluation of grass and legume production potential in Kendu Bay, South West Kenya. KARI: Participatory technology development for soil management by smallholders in Kenya. Proceedings of the 2nd 
Scientific Conference on the Soil Management and Legume Research Network Projects, Mombasa, Kenya.

Masinde AA, Ojowi MO, Mbugua DM, Odongo JA, Shisya MA (2002) Effect of organic and inorganic fertilisers and their combination on napier grass dry matter yields in South west Kenya. In: Participatory technology development by small holders in Kenya. Proceedings of the 2nd scientific conference of the soil management and legume research network projects, 2, Mombasa, Kenya, Jun 2000. KARILegume Research Network Project.

Mpangane P, Ayisi K, Mishiyi M, Whitebread A (2004) Grain yield of maize grown in sole and binary cultures with cowpea and lablab in the Limpopo province of South Africa. In: Whitbread A, Bruce C (2004) Tropical legumes for sustainable farming systems in Southern Africa and Australia. URL: http:/hdl.handle.net/102.100. $100 / 186500$ ?index $=1$

Mtengeti EJ, Urio NA, Mlay GI (2001) Intensive fodder gardens for improving forage availability for smallholder dairy production in Hai District, Tanzania. In: Stares JE et al. (eds): The complementarity of feed resources for Animal production in Africa. URL: https:// books.google.co.ke/books?id=xjGVx-vPXBkC\&pg=PA129\&lpg= PA129\&dq $=$

Mubiru S, Ebong C, Rubaire-Akiiki C, Kabirizi J, Odur A, Nakiganda A, Ndyanabo W, Bareeba F, Halberg N (2001) Adaptation of feed resource utilisation techniques to smallholder dairy farms in Masaka. In: Paper presented at the NARO Conference in December 2001 (p.1).

Mugerwa S, Babiker S, Habonayo G, Nijimbere A, Kayiwa S, Zziwa E, Njarui D (2011) A comparative analysis of phosphorus fertilizer regimes on seed production of Lablab in East and Central Africa. Int J Agron Agric Res 1(2):20-27 URL: https://innspubnet. wordpress.com/2016/12/31/a-

Muhr L, Tarawali A, Peters M, Schultze-Kraft R (2001) Acceptability of forage legumes for improved fallows - First experiences of agropastoralists in subhumid southwest Nigeria. Exp Agric 37(4):495$507 \mathrm{https}: / /$ doi.org/10.1017/S0014479701000436

Muinga RW, Thorpe W, Topps JH, Mureithi JG (1992) Responses to a Pennisetum purpureum (Napier grass) basal diet harvested at two different heights and fed with three levels of Leucaena forage to crossbred dairy cows in the subhumid tropics. In: Stares JE et al. (eds) Joint Feed Resources Network Workshop on the Complementarity of feed resources for animal production in Africa, Gaborone (Botswana), 4-8 Mar 1991. URL: https://books. google.co.ke/books?id=xjGVx-vPXBkC\&pg=PA75\&lpg= PA75\&dq=

Muinga RW, Thorpe W, Topps JH (1993) Lactational performance of Jersey cows given napier fodder (Pennisetum purpureum) with and without protein concentrates in the semi-humid tropics. Trop Anim Health Prod 25(2):118-128. https://doi.org/10.1007/bf02236519

Mupangwa W, Nemasasi H, Muchadeyi R, Manyawu GJ (2003) Residual effects of forage legumes on subsequent maize yields and soil fertility in the smallholder farming sector of Zimbabwe. In: Waddington SR (ed) (2003) Grain Legumes and Green Manures for Soil Fertility in Southern Africa: Taking Stock of Progress. Proceedings of a conference held 8-11 October 2002 in Vumba, Zimbabwe. URL: https://books.google.co.ke/books?id=

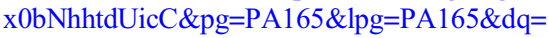

Mureithi JG, Thorpe W (1996) The effects of herbaceous legume intercropping and mulching on the productivity of napier grass (Pennisetum purpureum) and total forage yield in coastal lowland Kenya. In: Ndikumana J, Thorpe W, Leeuw P (eds) (1993) Sustainable Feed Production and Utilisation for Smallholder Livestock Enterprises in Sub-Saharan Africa. Proceedings of the Second African Feed Resources Network (AFRNET) Workshop held in Harare, Zimbabwe (pp. 45-50).

Murungweni C, Mabuku O, Manyawu GJ (2004) Mucuna, lablab and paprika calyx as substitutes for commercial protein sources used in dairy and pen-fattening diets by smallholder farmers of Zimbabwe. In: Whitebread E, Pengelly B (2004) Tropical legumes for sustainable farming systems in southern Africa and Australia, 115 pg. 126.

Mutegi JK, Mugendi DN, Verchot LV, Kung'u JB (2008) Combining napier grass with leguminous shrubs in contour hedgerows controls soil erosion without competing with crops. Agrofor Syst 74(1):3749. https://doi.org/10.1007/s10457-008-9152-3

Mutimura M, Everson T (2012) On-farm evaluation of improved Brachiaria grasses in low rainfall and aluminium toxicity prone areas of Rwanda. Int J Biodiv Conserv 4(3):137-154. https://doi.org/10. 5897/IJBC10.121

Muyekho F, Mose L (2000) Economic evaluation of "Tumbukiza" as an alternative method for increasing napier grass (Pennisetum purpureum) productivity on smallholder farms in North Rift Valley region of Kenya. KARI: Participatory Technology Development for Soil Management by smallholders in Kenya. In: Proceedings of the 2nd Scientific Conference of the Soil Management and Legume Research Network Projects, Mombasa, Kenya.

Muyekho F, Cheruiyot D, Kapkusum G (2000) Effects of the "Tumbukiza" method of planting napier grass (Pennisetum purpureum) on the quantity and quality of forage on smallholder farms in Kenya. In: Murethi, Gachene, Muyekho, Onyengo, Mose, Magenya (eds) Participatory Technology Development for soil management by smallholders in Kenya: Proceedings of the 2nd Scientific Conference of the Soil Management and Legume Research Network Projects, June 2000, Mombasa, Kenya (p. 551).

Ngwa A, Tawah C (2002) Effect of supplementation with leguminous crop residues or concentrates on the voluntary intake and performance of Kirdi sheep. Trop Anim Health Prod 34(1):65-73. https://doi.org/10.1023/a:1013789929102

Niang A, Styger E, Gahamanyi A, Hoekstra D, Coe R (1998) Fodderquality improvement through contour planting of legume-shrub/ grass mixtures in croplands of Rwanda highlands. Agrofor Syst 39(3):263-274. https://doi.org/10.1023/A:1005983129712

Njarui D (2007) Enhancing livestock feed supply by integrating selected forage legumes in semi-arid-arid region of Eastern Kenya (Doctoral dissertation, $\mathrm{PhD}$ thesis, Egerton University, Njoro, Kenya).

Njarui D, Wandera F, Muinga R (2000a) Evaluation of selected forage legumes as supplementary feed for Kenya dual-purpose goat in semi-arid region of Eastern Kenya. In: Participatory Technology for Soil management by Small holders in Kenya. Proceedings of the 2nd Scientific Conference of the Soil Management and Legume Research Networks Projects, June 2002, Mombasa, Kenya. pp 357-368. Kenya Agricultural Research Institute Publication, Nairobi, Kenya.

Njarui D, Wandera F, Mureithi J (2000b) Potential of Jack bean as a feed supplement for kenya dual purpose goats in the semi-arid Eastern Kenya. In: KARI: Participatory technology development for soil management by smallholders in Kenya. Proceedings of the 2nd Scientific Conference of the Soil Management and Legume Research Network Projects, Mombasa, Kenya.

Njoka-Njiru E, Njarui M, Abdulrazak S, Mureithi J (2006) Effect of intercropping herbaceous legumes with napier grass on dry matter yield and nutritive value of the feedstuffs in semi-arid region of Eastern Kenya. Agric Trop Subtrop 39(4):255-267

Njwe R, Donfack N, Djoukam J, Endeley H (1992) Performance of associations of Brachiaria ruziziensis with Desmodium intortum, Desmodium uncinatum and Stylosanthes guianensis at Dschang, Cameroon. In: Stares J et al. (eds) Joint Feed Resources Network Workshop on the Complementarity of Feed Resources for Animal Production in Africa, Gaborone (Botswana), 4-8 Mar 1991.

Nyambati E, Sollenberger L, Kunkle W (2003) Feed intake and lactation performance of dairy cows offered napier grass supplemented with legume hay. Livest Prod Sci 83(2-3):179-189. https://doi.org/10. 1016/S0301-6226(03)00094-0 
Nzabi AW, Tana P, Masinde A, Gesare M, Ngoti B, Mwangi G (2000) On-farm soil erosion control experiment using exotic grasses and locally available materials in Nyamonyo and Kakingusa villages of southwest Kenya. In Mureithi et al. (eds) Participatory technology development for soil management by smallholders in Kenya. A compilation of selected papers presented at the soil management and legume research network projects conference, Kanamai, Mombasa (Kenya), 24-26 March 1997: 39-44.

Ogedegbe S, Ogunlela V, Olufajo OO, Odion EC (2012) Mineral content of Lablab (Lablab purpureus L. Sweet) herbage as influenced by phosphorus application, cutting height and age of cutting at Samaru. Nigeria Asian J Crop Sci 4(1):1-11. https://doi.org/10.3923/ajcs. 2012.1.11

Ojo V, Dele P, Amole T, Anele U, Adeoye S, Hassan O, Olanite J, Idowu O (2013) Effect of intercropping Panicum maximum var. Ntchisi and Lablab purpureus on the growth, herbage yield and chemical composition of Panicum maximum var Ntchisi at different harvesting times. Pakistan J Biol Sci 16(22):1605-1608. https://doi.org/10. 3923/pjbs.2013.1605.1608

O'Neill M, Angima S, Duinker B, Okoba B (2002) Fodder production from contour hedges in the central Kenyan highlands. J Sustain Agric 20(3):57-67. https://doi.org/10.1300/J064v20n03_06

Pamo ET, Fonteh FA, Tendonkeng F, Kana JR, Boukila B, Djaga PJ, Fomewang G II (2006a) Influence of supplementary feeding with multipurpose leguminous tree leaves on kid growth and milk production in the West African dwarf goat. Small Rumin Res 63(1-2): 142-149. https://doi.org/10.1016/j.smallrumres.2005.02.011

Pamo ET, Tendonkeng F, Kana JR, Boukila B, Nanda AS (2006b) Effects of Calliandra calothyrsus and Leucaena leucocephala supplementary feeding on goat production in Cameroon. Small Rumin Res 65(1-2):31-37. https://doi.org/10.1016/j.smallrumres.2005.05. 023

Paterson RT, Kiruiro E, Arimi HK (1999) Calliandra calothyrsus as a supplement for milk production in the Kenya highlands. Trop Anim Health Prod 31(2):115-126. https://doi.org/10.1023/a: 1005119808090
Rahetlah VB, Randrianaivoarivony JM, Andrianarisoa B, Razafimpamoa LH, Ramalanjaona VL (2012) Yield and quality of Brachiaria sp. cv Mulato-forage perennial peanut (Arachis pintoi) mixture in the highlands of Madagascar. Livestock Research for Rural Development, 24 (10). URL: http://www.lrrd.org/lrrd24/10/rahe24171.htm

Ruto C, Muyekho F, Rono S, Onyango R, Bunyatta D, Nyambati E (2000) Participatory evaluation of the production and utilisation of improved forages under different fertiliser regimes, Keiyo district. KARI: Participatory technology development for soil management by smallholders in Kenya. Proceedings of the 2nd Scientific Conference on the Soil Management and Legume Research Network Projects, Mombasa, Kenya.

Schlecht E, Mahler F, Sangaré M, Susenbeth A, Becker K (1995) Quantitative and qualitative estimation of nutrient intake and faecal excretion of zebu cattle grazing natural pasture in semi-arid Mali. In: Powell JM et al. (1993) International Conference on Livestock and Sustainable Nutrient Cycling in Mixed Farming Systems of SubSaharan Africa, Addis Ababa (Ethiopia), 22-26 Nov 1993.

Singh BB, Ajeigbe HA, Tarawali SA, Fernandez-Rivera S, Abubakar M (2003) Improving the production and utilization of cowpea as food and fodder. Field Crop Res 84(1-2):169-177. https://doi.org/10. 1016/S0378-4290(03)00148-5

Turinawe A, Mugisha J, Kabirizi J (2012) Socio-economic evaluation of improved forage technologies in smallholder dairy cattle farming systems in Uganda. J Agric Sci 4(3):163. https://doi.org/10.5539/ jas.v4n3p163

Wegad D, Ndumbe RD (1987) The effect of different protein supplements on weight gain and voluntary intake of maize stover by cattle. ARNAB (1987) Utilization of agricultural by-products as livestock feeds in Africa, 99-102.

Publisher's note Springer Nature remains neutral with regard to jurisdictional claims in published maps and institutional affiliations. 